\title{
Biomedical Application, Patent Repository, Clinical Trial and Regulatory Updates on Hydrogel: An Extensive Review
}

\author{
Sradhanjali Mohapatra ${ }^{1,+}$, Mohd. Aamir Mirza ${ }^{1,+}{ }^{(0)}$, Ayah Rebhi Hilles ${ }^{2}$, Foziyah Zakir ${ }^{3}{ }^{(0)}$, \\ Andreia Castro Gomes ${ }^{4,5} \oplus^{\circ}$, Mohammad Javed Ansari ${ }^{6}{ }^{\circ}$, Zeenat Iqbal ${ }^{1, *}$ and Syed Mahmood $7,8, *$
}

1 Department of Pharmaceutics, School of Pharmaceutics Education and Research (SPER), Jamia Hamdard, New Delhi 110062, India; sibanee@gmail.com (S.M.); aamir_pharma@yahoo.com (M.A.M.)

2 International Institute for Halal Research and Training (INHART), International Islamic University Malaysia, Kuala Lumpur 53100, Malaysia; ayah.hilles90@gmai.com

3 Department of Pharmaceutics, School of Pharmaceutical Sciences, Delhi Pharmaceutical Sciences and Research University, New Delhi 110017, India; foziyahzakir@gmail.com

4 Centre of Molecular and Environmental Biology (CBMA), Universidade do Minho, Campus de Gualtar, 4710-057 Braga, Portugal; agomes@bio.uminho.pt

5 Institute of Science and Innovation for Bio-Sustainability (IB-S), Universidade do Minho, Campus de Gualtar, 4710-057 Braga, Portugal

6 Department of Pharmaceutics, College of Pharmacy, Prince Sattam Bin Abdulaziz University, Alkharj 11942, Saudi Arabia; mj.ansari@psau.edu.sa

7 Department of Pharmaceutical Technology, Faculty of Pharmacy, Universiti Malaya, Kuala Lumpur 50603, Malaysia

8 Centre for Natural Products Research and Drug Discovery (CENAR), Universiti Malaya, Kuala Lumpur 50603, Malaysia

check for updates

Citation: Mohapatra, S.; Mirza, M.A.; Hilles, A.R.; Zakir, F.; Gomes, A.C.; Ansari, M.J.; Iqbal, Z.; Mahmood, S. Biomedical Application, Patent Repository, Clinical Trial and Regulatory Updates on Hydrogel: An Extensive Review. Gels 2021, 7, 207. https://doi.org/10.3390/gels7040207

Academic Editors: Esmaiel Jabbari and Mohsen Akbari

Received: 5 September 2021

Accepted: 8 November 2021

Published: 12 November 2021

Publisher's Note: MDPI stays neutral with regard to jurisdictional claims in published maps and institutional affiliations.

Copyright: (c) 2021 by the authors. Licensee MDPI, Basel, Switzerland. This article is an open access article distributed under the terms and conditions of the Creative Commons Attribution (CC BY) license (https:// creativecommons.org/licenses/by/ $4.0 /)$
* Correspondence: zeenatiqbal@jamiahamdard.ac.in (Z.I.); syedmahmood@um.edu.my (S.M.)

+ Authors share equal contribution.

Abstract: Hydrogels are known for their leading role in biomaterial systems involving pharmaceuticals that fascinate material scientists to work on the wide variety of biomedical applications. The physical and mechanical properties of hydrogels, along with their biodegradability and biocompatibility characteristics, have made them an attractive and flexible tool with various applications such as imaging, diagnosis and treatment. The water-cherishing nature of hydrogels and their capacity to swell-contingent upon a few ecological signals or the simple presence of water-is alluring for drug conveyance applications. Currently, there are several problems relating to drug delivery, to which hydrogel may provide a possible solution. Hence, it is pertinent to collate updates on hydrogels pertaining to biomedical applications. The primary objective of this review article is to garner information regarding classification, properties, methods of preparations, and of the polymers used with particular emphasis on injectable hydrogels. This review also covers the regulatory and other commerce specific information. Further, it enlists several patents and clinical trials of hydrogels with related indications and offers a consolidated resource for all facets associated with the biomedical hydrogels.

Keywords: hydrogel; biomaterial; patents; injectable; regulatory; drug delivery

\section{Introduction}

Hydrogels are polymeric matrices having a three-dimensional configuration that absorb water and undergo swelling but do not dissolve (short term) and facilitate the controlled drug-release into our body [1]. The high thermodynamic affinity of this class of materials towards the solvent is contributed towards its swelling property. They bear a physical resemblance to living tissues because of their significant water content and consistency. There is also a unique type of hydrogel, called as intelligent gels or smart gels. They can perceive the stimuli and respond by exhibiting changes in their physical or chemical behaviors and subsequent release of the entrapped drug. Hydrogels are widely 
explored as a tool for biomedical applications due to their ability to form crosslink under mild conditions coupled with high versatility, excellent biocompatibility, and permeability to oxygen, nutrient and tunable material's properties.

Hydrogels can be delegated as a tool that meets the particular necessities to focus on the medication to the specific region and control its release. Properties of a hydrogel such as hydrolytic, enzymatic and ecological play a role to control the delivery of medication with the desired objectives such as extending their drug release profile, and expanding the choice of medicaments different drug delivery applications [2]. The hydrophilic functional groups attached to the polymeric backbone of hydrogels are responsible for their affinity to absorb water. Crosslinking between the network chains is answerable for its resistance to dissolution [3]. Both natural and synthetic materials can be used in the preparation of hydrogels. Synthetic hydrogels have replaced their natural counterparts from the last few decades due to their high water-absorbing capacity, long shelf life, high gel strength, and better stability profile in sharp fluctuating temperatures. Again, well-defined structures of synthetic polymers can be modified to yield tailor-able functionality and degradability [4].

Hydrogel has a long history of evolution and has been reported upon with diverse classifications. The term hydrogel was initially coined in the year 1894 by Van Bemmelen [5]. The first-ever synthetic hydrogel poly(2-hydroxyethyl methacrylate) (pHEMA) was synthesized by scientists DuPont in 1936, and the first drug delivery hydrogel Cervidil ${ }^{\circledR}$ for cervical ripening was launched in 1995 [5]. Since then, continuous research and development in hydrogel has led to a total of 329,350 patents filed until today. However, the first generation of hydrogels aimed at developing artefact with high swelling and good mechanical properties with relatively simple rationale. It comprises chemical modifications of a monomer or polymer with an initiator by involving many cross-linking procedures. In comparison, the second generation of hydrogel can produce a response concerning specific stimuli, such as variations in temperature, pressure, light, magnetic fields, electrical fields, $\mathrm{pH}$ or concentration of specific molecules in solution. These specific stimuli can be exploited to trigger specific events. However, the third generation of hydrogels focusing on the study and development of stereo complexed materials (e.g., PEG-PLA interaction) [6,7] or formed by crosslinking due to other physical interactions [8,9]. Nowadays, research focuses on developing the so-called "smart hydrogels", polymeric matrices having a broad spectrum of tunable properties. Nevertheless, there are several difficulties associated with utilizing hydrogels such as hydrophobicity of the active ingredients, which may create problems during medication conveyance during treatment. The water-cherishing polymeric center is most likely not an ideal site to hold incongruent hydrophobic medications. Other hydrogels have frail elasticity, which occasionally causes early arrival of the medication before landing at the objective site. In recent years, research on hydrogel has been continuously increased which can be evident from the Figure 1. Further, these statistics reveal a many fold increase in the number of patent publications related to the injectable hydrogel as compared to hydrogel from the last two decades.

Hydrogel controlled medication delivers the active constituent by utilizing framework gadgets that permit diffusion of medication and discharge through a cross-section (pores) that are loaded up with water. In the supply delivery framework, the hydrogel film is covered on a medication containing center, creating sections, cases and circles or having a high medication focus on the focal point of the framework to encourage a steady medication discharge rate. While the supply delivery framework produces time-free and consistent medication discharge using the macromolecular lattice. Lattice delivery is time-subordinate medication discharge in which the underlying delivery rate is relative to the square base of time instead of being steady. The drugs are dispersed in a polymer, and when they come into contact with water or bio-fluid they will begin to swell. During swelling, it will expand, which will ease the spread of the drug along with the relaxation of the polymer chain that supports time-independent and constant drug release kinetics. The active ingredient diffuses from the dispersed drug having a higher concentration within the hydrogel to its surrounding environment with lower concentration due to the concentration gradient. 
This method combines both the processes of diffusion and swelling for enabling drug release [10].

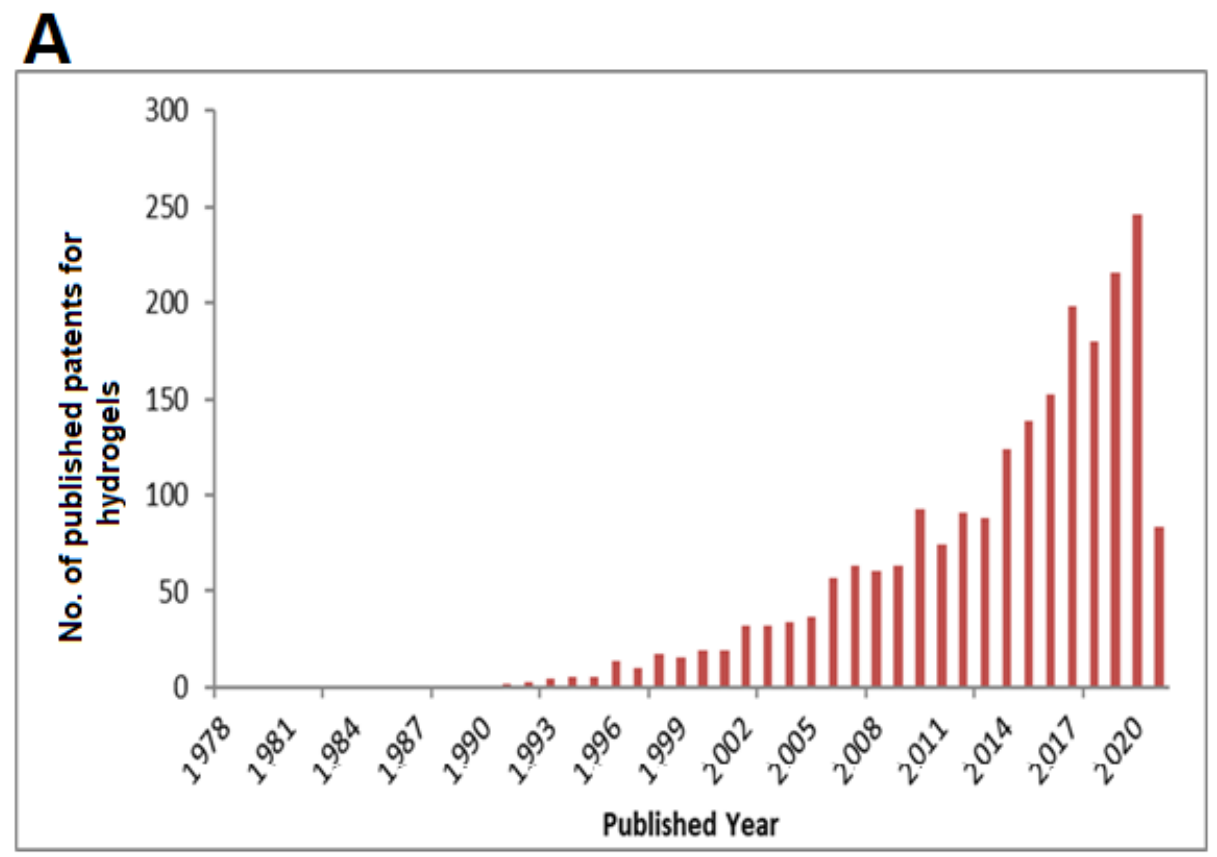

B

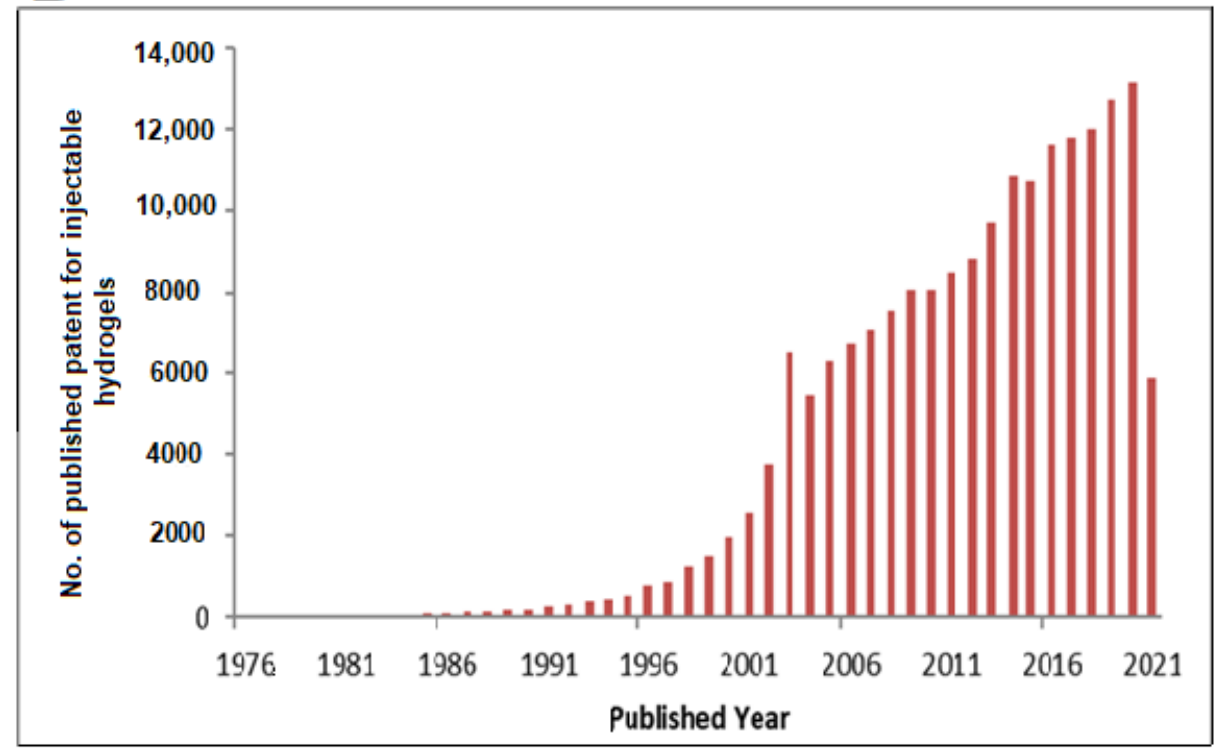

Figure 1. Histogram representing the published patents related with the hydrogels (A); and injectable hydrogels (B).

The following mathematical model can explain the process of swelling of a hydrogel matrix:

$$
\mathrm{dc} / \mathrm{dt}=\Delta \mathrm{D}(\mathrm{t}) \Delta \mathrm{c}-\Delta(\mathrm{cu})
$$

where, $\mathrm{dc} / \mathrm{dt}=$ change in concentration with time,

$c=$ concentration of drug in the hydrogel

$\mathrm{D}(\mathrm{t})=$ diffusion coefficient

$\Delta \mathrm{c}=$ concentration gradient

$\mathrm{u}=$ swelling capacity of the hydrogel. 
The diffusion process is governed by Fick's law of diffusion which states that diffusion occurs from a region of high concentration to the low concentration:

$$
\mathrm{dc} / \mathrm{dt}=\chi \mathrm{d} 2 \mathrm{c} / \mathrm{d} \times 2
$$

where $\chi=$ diffusivity,

$\mathrm{t}=$ time

$\mathrm{x}=$ dimension (in length)

Hydrogels significantly improve the remedial result of medication conveyance and have discovered gigantic clinical use. The worldly and three-dimensional conveyance of macromolecular medications have extraordinarily improved through hydrogel used for drug delivery [2]. Even though medication conveyance utilizing hydrogels has not been liberated from difficulties, consistent upgrades are being made to distinguish the hydrogel configuration most appropriate for explicit medication delivery purposes. However, hydrogels have recently drawn great attention for use in a diversified biomedical field for various applications such as the sustained release of active medicaments, cell therapeutics, cosmetics use, tissue regeneration and wound healing, etc. The following figure, Figure 2, illustrates the application of various hydrogels used in different body parts of humans.

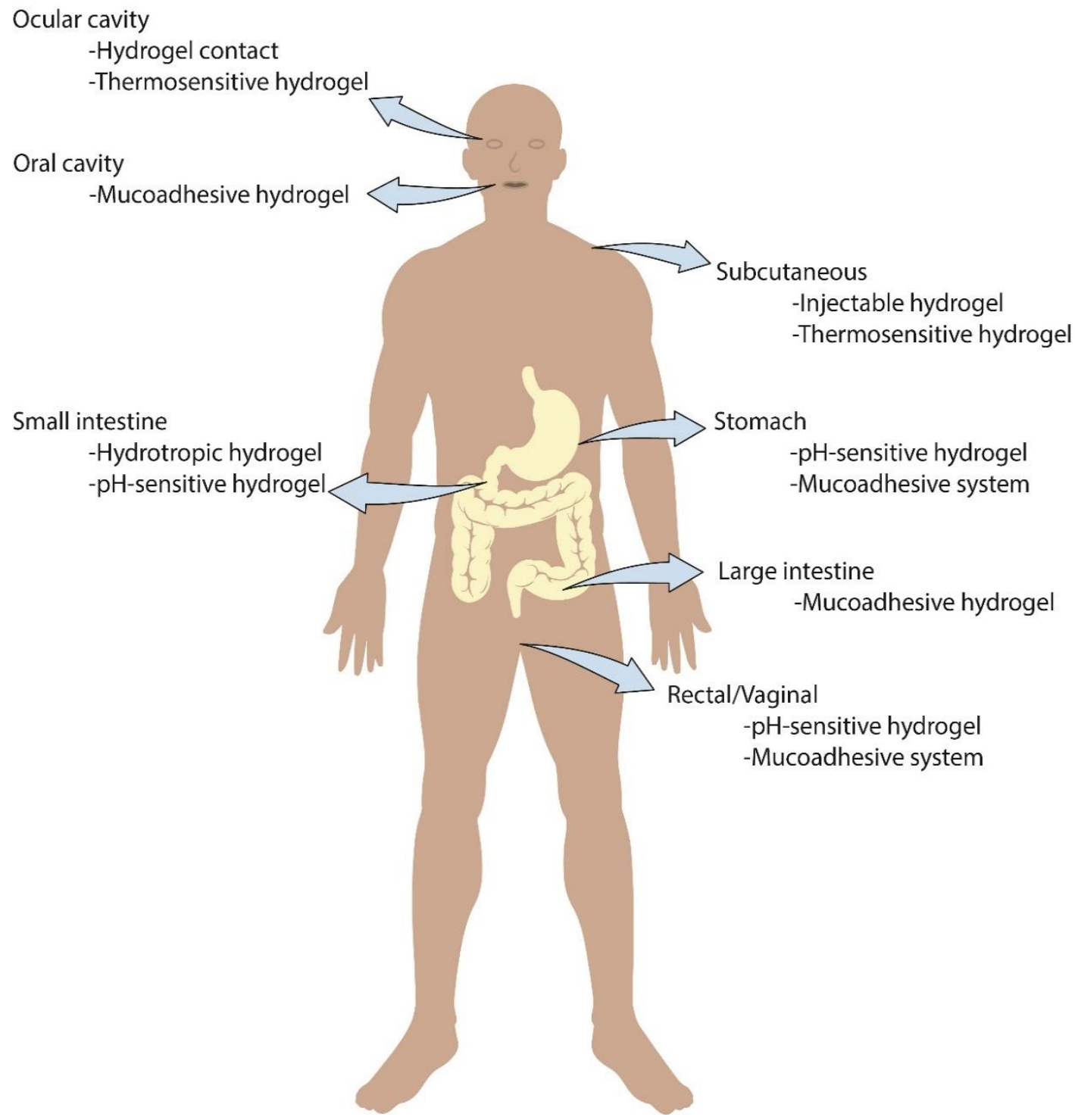

Figure 2. Applications of hydrogels in different human body parts. 
This review brings together different aspects of the hydrogel, such as classification, properties, preparation methods, the polymer used, and applications in the biomedical field. It specifically elaborates the injectable hydrogels enlisting their formulations for mitigating diseases. Further, it emphasizes on the regulatory aspects of commercial hydrogel highlighting the information related to certain ingredients. Additionally, it encompasses several patents, clinical trials and existing commercial hydrogel products with related indications. This review may act as a resource for the hydrogel system concerning the biomedical area covering all the essential aspects and may pave the way to conduct future research in this particular field.

\section{Classification of Hydrogel-Based System}

There are several opinions found in the literature concerning the classification of hydrogel. They may be classified on the basis of the source from which they are obtained, physical properties, structures, crosslinking present, the ionic charge on bound groups, preparation methods and stimuli given to produce a specific response. Based on the above, the classification of the hydrogels are shown in Figure 3.

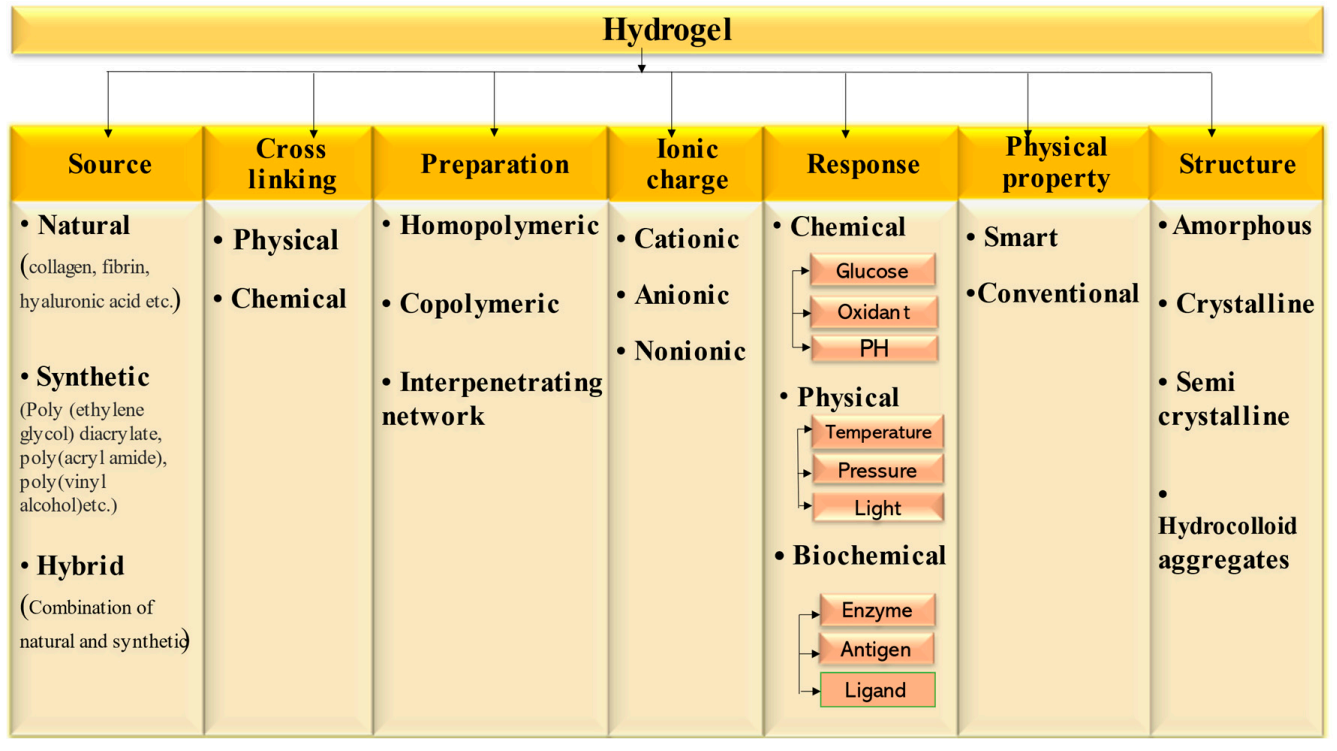

Figure 3. Classification of hydrogel-based systems.

\section{Polymers Used for Fabricating Hydrogel}

Natural polymers are usually composed of components of proteins and extracellular matrix or derivatives of natural materials such as alginate, chitosan and skill fibers which makes them inherently bioactive, biodegradable, biocompatible, nontoxic and promote many cellular functions for different biomedical applications. The two drawbacks associated with natural hydrogels are that they have poor mechanical properties. Additionally, it is unclear about the correlation between the mechanical properties and polymerization or gelation conditions. Further, they offer difficulty in being manipulated as they have a high batch variation that may lead to poor reproducibility. In contrast, synthetic hydrogels are more reproducible, although their final structure can also depend on polymerization conditions, demanding rigorous control of the preparation protocol. So, it can be concluded that synthetic hydrogels offer more flexibility for altering chemical composition and mechanical properties than natural counterparts and are more prevalent. A few commonly used natural and synthetic polymers for hydrogels are enlisted in the following Table 1 [11,12]. 
Table 1. Polymers commonly used in various hydrogel formulations.

\begin{tabular}{ccc}
\hline Natural Polymer & Synthetic Polymer & Hybrid Polymer \\
\hline Hyaluronic acid & PEG-PLA-PEG & P (PEG-co-peptides) \\
Pectin & PEG-PLGA-PEG & P-(HPMA-g-peptide) \\
Alginic acid & PEG-PCL-PEG & P (PLGA-co-serine) \\
Carrageenan & PLA-PEG-PLA & Alginate-g-(PEO-PPO-PEO) \\
Chondroitin sulphate & PHB & HA-g-NIPAAm \\
Dextrin sulphate & P (PEG/PBO terephthalate) & Collagen-n-acryl ate \\
Chitosan & Polyurethane & Alginate-acryl ate \\
Polylysine & Polyimide & \\
Collagen (and gelatine) & Polyvinylpyrrolidone & \\
Carboxy methylchitin & Polyvinyl alcohol & \\
Fibrin and silk fibroin & Polyacrylate & \\
Dextrin & Polythene oxide & \\
Pullulan & Polymethacrylate & \\
Agarose & & \\
Elastin & & \\
Glycosaminoglycans & & \\
Decellularized Hydrogels & &
\end{tabular}

\section{Properties of Hydrogel}

It is imperative to have a basic understanding of the gel properties so that a suitable gel delivery system can be designed. The interactions between the gel and the solute molecules can be better understood after studying the following properties.

\subsection{Swelling}

Hydrogels are crosslinked macromolecular polymeric networks that can swell in a liquid medium. The swelled polymer acts as a filter which allows partial diffusion of solute molecules. The polymer network is able to retain the solvent by forming a gel and will not dissolve if crosslinked. The presence of a hydrophilic functional group attached to the backbone and the difference in the osmotic pressure between the gel phase and the solvent phase is responsible for water absorption by the hydrogel. In hydrogel, the presence of water determines the overall permeation of nutrients in and out from the gel. Thermoresponsive hydrogels are one of the other categories of hydrogels having high biomedical interest. At room temperature these appear as fluid but convert into viscous gel as they get exposed to the body temperature, which lengthens their staying time, hence prolonging their release rate. They have the ability to undergo phase transition or swell/deswell at ambient alteration of temperature. Concentrate solution of poloxamer with water is one good example of thermoreversible gel widely used for tissue engineering applications nowadays [13,14]. Further, the rate and degree of swelling, controls the release patterns of drugs and solvents from hydrogel polymeric networks.

Researchers use several methods to determine the relative free and bound water contents with respect to total water content. It indicates the swelling property of the hydrogel. Some of the common techniques used for routine investigation of water content in hydrogels are: small molecular probes, DSC and proton NMR. Additionally, evaluation of swelling properties of the hydrogel serves as a measure for many of their properties such as mechanical properties, degree of crosslinking, rate of degradation and many more. Evaluation of the swelling and swollen state stability may help distinguish between crosslinked gels and the non-crosslinked original polymer [15,16].

\subsection{Mechanical Properties}

Generally, the mechanical property of hydrogel is linked to their water contents and cross linking density. The stiffness of the gel can be increased by increasing the degree of crosslinking or can be decreased by heating the material. An ideal hydrogel should be mechanically robust with rapid diffusion and response rate. The mechanical properties can 
be changed by a wide range of variables and causes, so it should be analyzed based on the aim of the study, types of material and the condition, etc. The mechanical properties of the hydrogel can be determined by texture profile analyzer or a rheometer by calculating young modulus, Poisson modulus, storage and loss moduli, etc. Currently, more efforts have been made to construct hydrogels with substantial mechanical performance. Double-network, topological, nanocomposite, macromolecular microsphere composite and supramolecular hydrogels are among the successful strategies for fabricating high-strength hydrogel. These are promising multifunctional materials having sufficient and robust mechanical properties that can be used successfully as tissue engineering scaffolds. The degree of stiffness of the hydrogel is determined based on its application area, i.e., where it has to be applied. For example, to seed osteoblast cells, a more rigid material is required than for culturing adipocytes [17]. However, materials characterization, tensile and compressive tests are basic methods for mechanical performance evaluation $[18,19]$.

\subsection{Porosity and Permeation}

This is another important property that can simply indicate the presence of a void cavity inside the bulk. There may exist smaller pores within the network or may be formed in hydrogels during synthesis (by phase separation). It is beneficial to control the porosity for several applications, such as the tunable release of macromolecules, optimal cell migration in hydrogel-based scaffolds, etc. It has been found that porosity is a significant factor that influences the swelling and drug release behavior of the hydrogels [20]. The presence of a porous structure improves the drug release while non-porous hydrogels led to a very slow release. Additionally, the presence of pores can help in sustain release drugs for prolonged periods of time [21].

Porosity can be assessed by theoretical methods, such as liquid displacement method, Archimedes method, etc., with the use of optical and electronic microscopy. Some other methods such as gas pycnometer method, gas adsorption, capillary flow porosity have also been reported. One of the other important assays is X-ray microtomography [22]. Microscopy is another technique that can be used in assays involving hydrogels by which surface morphology and topography can be assessed. It involves the use of optical microscope, scanning electron microscope (SEM), transmission electron microscope (TEM), tunnelling microscope, atomic force microscopy (AFM) [23]. Additionally, thermoporometry helps to determine pore size based on melting or crystallization point of water molecules confined into the pores of hydrogels. It has advantages over other techniques, as it analyzes the sample in dried state [24-26]. It is based on analyzing the thermodynamic behavior of water relating to its interaction with polymers and provide a range of pore sizes in nano scale [27].

\subsection{Crosslinking}

Although crosslinking is not a basic property of hydrogels, it affects all the other material properties. It has some important characteristics, as it makes the hydrogel mechanically strong, and heat and erosion resistant. It may influence the rheological parameters, hydration and diffusion through skin [28]. The degree of crosslinking can be interconnected to every characteristic of a hydrogel, however the nature of crosslinking can vary a lot. The hydrogel's network can be obtained in many different ways such as physical crosslinking (by complex coacervation or ionic interaction), chemical crosslinking via crosslinker or by radiation crosslinking. By regulating the degree of crosslinking, we can control the property of the material and can optimize it for numerous applications from the same original polymer $[29,30]$. However, there are several disadvantages such as relatively inflexibility in their processing properties as they are insoluble and infusible [31].

\section{Method of Preparation}

Usually, hydrogels are prepared from hydrophilic monomers, but sometimes hydrophobic monomers are also used to achieve certain desirable attributes. Synthetic 
polymers are hydrophobic and used to provide mechanical strength and durability to the hydrogels. The main components to fabricate hydrogels are monomer, cross linker and initiator, along with water that acts as diluent to regulate the heat of the reaction. Crosslinking reactions in hydrogel can occur via different methods, such as utilizing reaction and ionizing radiation to produce free radicals that recombine, creating cross-links, entanglements, electrostatics, and crystalline formation.

Hydrogels are derived from polar monomers and undergo crosslinking reactions by linking polymer chains to form networks. Such alterations can improve the mechanical properties and viscoelasticity for numerous biomedical applications in the pharmaceutical fields. The general methods to produce physical and chemical gels are summarized in Figure 4 [32].

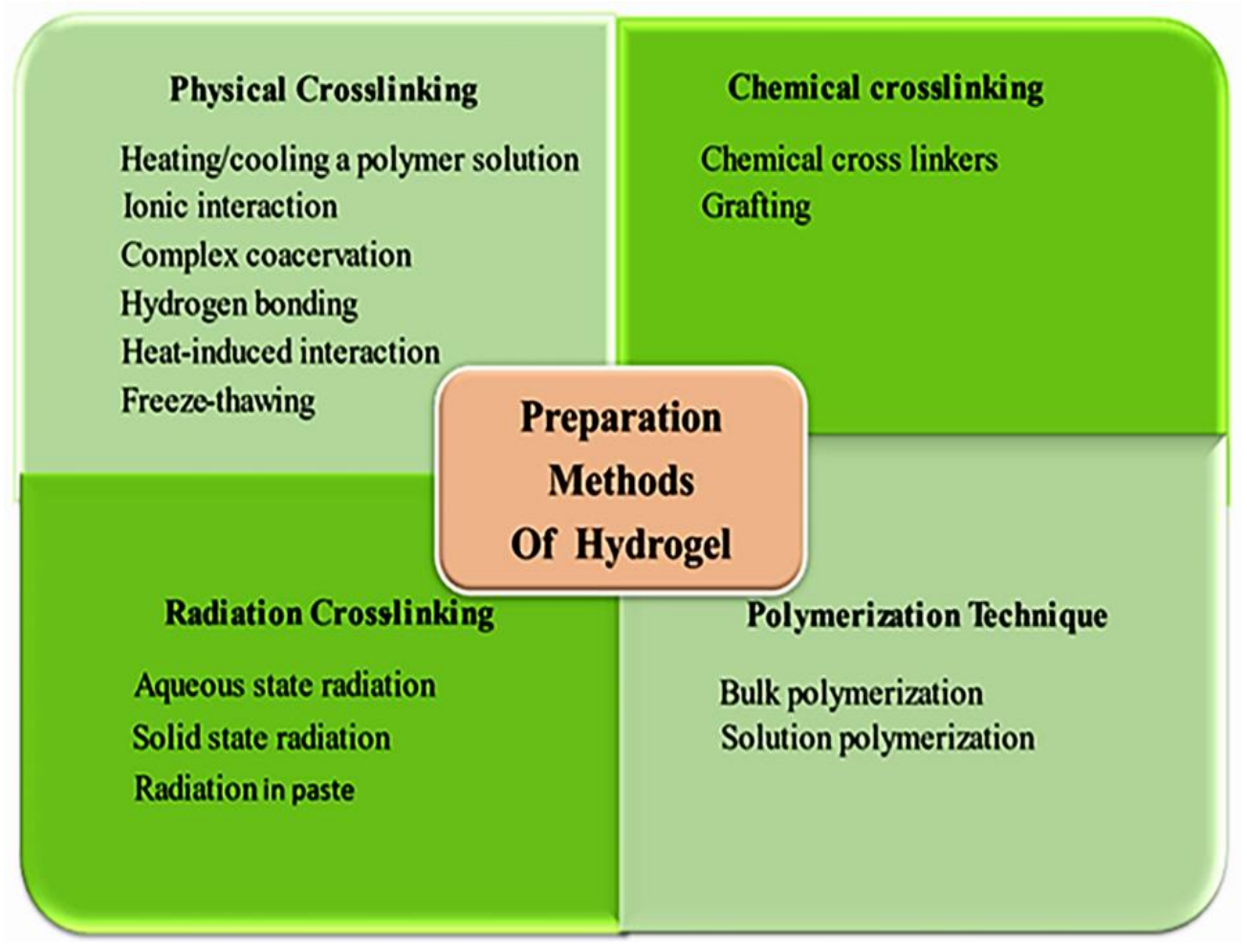

Figure 4. Different methods of preparation of hydrogel.

\section{Applications of Hydrogel}

Due to its versatility and flexibility, hydrogel possesses diversified applications such as biomedical, agriculture, sanitary diapers, dyes removal, heavy metal ions removal, biosensors, $\mathrm{pH}$-sensors, and super-capacitors, etc. [33]. The following section includes biomedical applications of hydrogels in areas of cosmetic technology, wound healing, contact lenses, drug delivery, and tissue engineering, etc. [12,34]. Figure 5 mentions the biomedical applications of hydrogel. Further, this section includes a list of patents and clinical trials (Tables 2 and 3) related to various hydrogel formulations, which give an idea about the current research conducted in this area. 


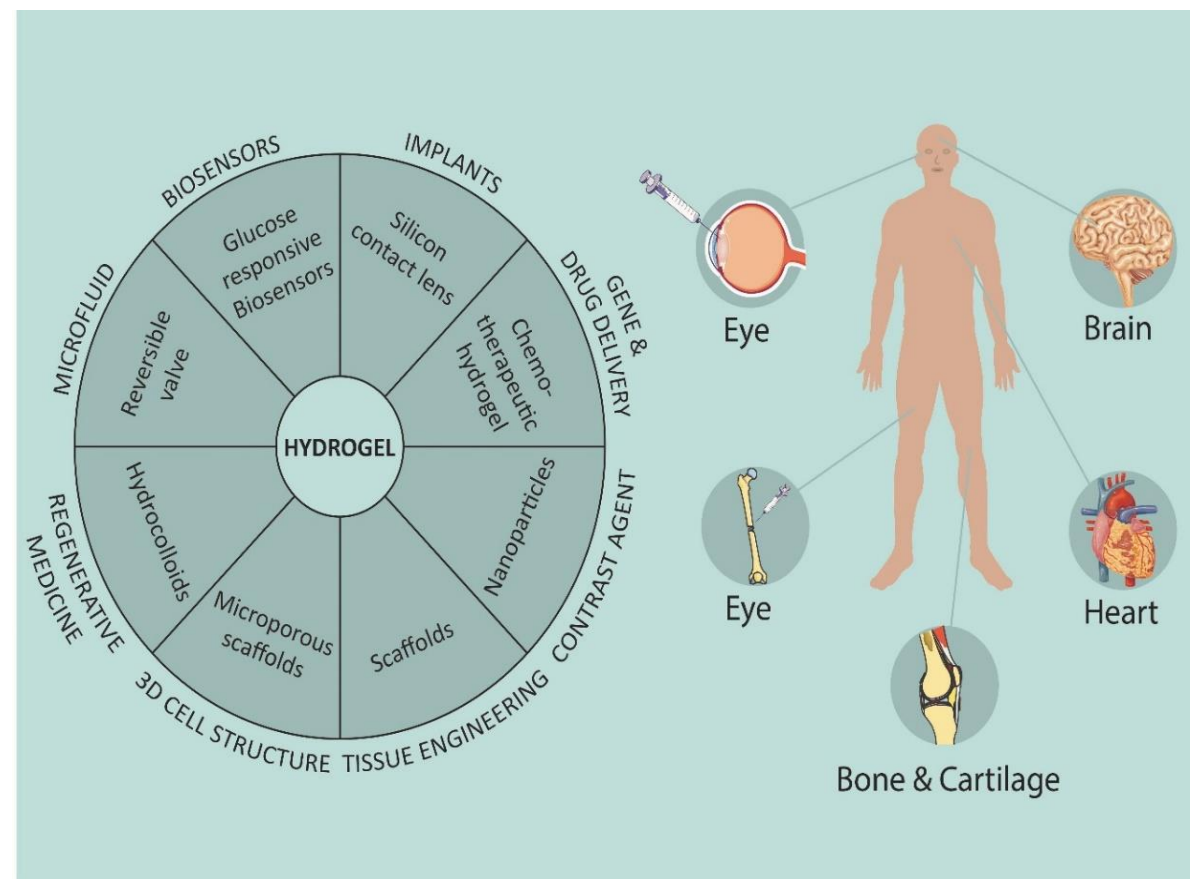

Figure 5. Possible biomedical applications of hydrogel.

Table 2. List of Patent for various hydrogel formulation.

\begin{tabular}{|c|c|c|c|c|}
\hline S. No. & Patent No./Country & Title & Disease/Problem & Details \\
\hline 1 & $\begin{array}{l}\text { US10799696B2 } \\
\text { United States }\end{array}$ & $\begin{array}{l}\text { Polymer formulations } \\
\text { for nasolacrimal } \\
\text { stimulation }\end{array}$ & Dry eye & $\begin{array}{l}\text { The hydrogel formulation (prepared by } \\
\text { a UV crosslinking process) permits } \\
\text { electrical stimulation of the lacrimal } \\
\text { gland, nasal or sinus tissue to } \uparrow \\
\text { production of tear and to treat dry eye }\end{array}$ \\
\hline 2 & $\begin{array}{l}\text { US20200085733A1 } \\
\text { United States }\end{array}$ & $\begin{array}{l}\text { Hypotonic hydrogel } \\
\text { formulations for } \\
\text { enhanced transport of } \\
\text { active agents at } \\
\text { mucosal surfaces }\end{array}$ & $\begin{array}{l}\text { Administered into } \\
\text { vagina or colorectum } \\
\text { for diagnostic, } \\
\text { prophylactic and } \\
\text { therapeutic purpose }\end{array}$ & $\begin{array}{l}\text { An aqueous polymeric hydrogel } \\
\text { (poloxamers) used as a barrier by } \\
\text { forming plug and/or used for the } \\
\text { delivery to a mucosal/epithelial surface } \\
\text { for therapeutic, preventive, diagnostic } \\
\text { or nutraceutical purpose }\end{array}$ \\
\hline 3 & $\begin{array}{l}\text { US20200114010A1 } \\
\text { United States }\end{array}$ & $\begin{array}{l}\text { Non-injectable } \\
\text { hydrogel formulations } \\
\text { for smart release }\end{array}$ & $\begin{array}{l}\text { The formulation } \\
\text { contains anti- } \\
\text { inflammatories, } \\
\text { anti-infectives, or } \\
\text { other therapeutic, } \\
\text { prophylactic, or } \\
\text { diagnostic agents that } \\
\text { can be administered } \\
\text { orally to produce } \\
\text { desire action }\end{array}$ & $\begin{array}{c}\text { A non-injectable } \\
\text { formulation/formulation for instillation, } \\
\text { with self-assembling hydrogels } \\
\text { designed of gelators, in the form of } \\
\text { capsules, tablets, oral suspensions, } \\
\text { rectal or vaginal suppositories, enemas, } \\
\text { and inserts }\end{array}$ \\
\hline 4 & $\begin{array}{l}\text { US20180023049A1 } \\
\text { United States }\end{array}$ & $\begin{array}{l}\text { Synthetic peptide } \\
\text { hydrogel formulations } \\
\text { for use as } \\
\text { extracellular matrix }\end{array}$ & $\begin{array}{c}\text { Cell culture } \\
\text { experimentation }\end{array}$ & $\begin{array}{l}\text { Synthetic peptide hydrogel solutions } \\
\text { having a pH level of about } 3.5 /<\text { and } \\
\text { having a tonicity within an isotonic } \\
\text { osmolality range }\end{array}$ \\
\hline 5 & $\begin{array}{l}\text { US20200360281A1 } \\
\text { United States }\end{array}$ & $\begin{array}{l}\text { A thermo-responsive } \\
\text { hydrogel for } \\
\text { intertumoral } \\
\text { administration as a } \\
\text { treatment in solid } \\
\text { tumor cancers }\end{array}$ & $\begin{array}{l}\text { Intra tumoral treatment } \\
\text { of solid cancer }\end{array}$ & $\begin{array}{l}\text { Injectable thermo-responsive hydrogel } \\
\text { forming a chitosan and genipin } \\
\text { interpenetrating scaffold by crosslinking } \\
\text { can effectively incorporate } \\
\text { chemotherapeutic drugs without any } \\
\text { loss of thermo-responsiveness }\end{array}$ \\
\hline
\end{tabular}


Table 2. Cont.

\begin{tabular}{|c|c|c|c|c|}
\hline S. No. & Patent No./Country & Title & Disease/Problem & Details \\
\hline 6 & $\begin{array}{l}\text { WO2019067406A1 } \\
\text { WIPO (PCT) }\end{array}$ & $\begin{array}{l}\text { Biomimetic, moldable, } \\
\text { self-assembled } \\
\text { cellulose silica-based } \\
\text { trimeric hydrogels and } \\
\text { their use as viscosity } \\
\text { modifying carriers in } \\
\text { industrial applications }\end{array}$ & $\begin{array}{l}\text { Use as low-cost and } \\
\text { safe carriers and } \\
\text { aqueous viscosity } \\
\text { modifiers in various } \\
\text { industrial and } \\
\text { medical applications }\end{array}$ & $\begin{array}{l}\text { A moldable, cellulose silica-based } \\
\text { hydrogels which is fully scalable }\end{array}$ \\
\hline 7 & $\begin{array}{l}\text { US20190127726A1 } \\
\text { United States }\end{array}$ & $\begin{array}{l}\text { Delivering enzyme } \\
\text { using an injectable } \\
\text { hydrogel depot }\end{array}$ & To deliver enzymes & $\begin{array}{l}\text { A delivery system for carrying an } \\
\text { injectable enzyme hydrogel formulation } \\
\text { consisting of an enzyme together with } \\
\text { other components }\end{array}$ \\
\hline 8 & $\begin{array}{l}\text { WO2017152112A2 } \\
\text { WIPO (PCT) }\end{array}$ & $\begin{array}{l}\text { Hydrogel systems for } \\
\text { skeletal interfacial } \\
\text { tissue regeneration } \\
\text { applied to epiphyseal } \\
\text { growth plate repair }\end{array}$ & $\begin{array}{l}\text { It can be applied } \\
\text { through numerous } \\
\text { different modalities } \\
\text { depending on the } \\
\text { nature of the } \\
\text { physical injury }\end{array}$ & $\begin{array}{l}\text { Biomaterials, systems, and methods for } \\
\text { guiding regeneration of an epiphyseal } \\
\text { growth plate or similar interfacial } \\
\text { tissue structures }\end{array}$ \\
\hline 9 & $\begin{array}{l}\text { JP6293254B2 } \\
\text { Japan }\end{array}$ & $\begin{array}{l}\text { Silicone hydrogel lens } \\
\text { with crosslinked } \\
\text { hydrophilic coating }\end{array}$ & Contact lens & $\begin{array}{l}\text { Coated silicone hydrogel contact lens } \\
\text { containing a surface coating of silicone } \\
\text { hydrogel and a non-silicone hydrogel } \\
\text { which is a crosslinked polymer } \\
\text { consisting of one or more cross-linkable } \\
\text { materials and a crosslinked } \\
\text { carboxyl-containing polymer material }\end{array}$ \\
\hline 10 & $\begin{array}{l}\text { CN105209016B } \\
\text { China }\end{array}$ & $\begin{array}{l}\text { Biocompatible } \\
\text { hydrogel polymer } \\
\text { matrices for } \\
\text { cell delivery }\end{array}$ & $\begin{array}{l}\text { A solid support that is } \\
\text { beneficial for cell } \\
\text { viability and } \\
\text { functionality }\end{array}$ & $\begin{array}{l}\text { Biocompatible hydrogel polymer } \\
\text { matrices, bioabsorbable and releases } \\
\text { cells at the target site, thus permitting } \\
\text { controlled delivery }\end{array}$ \\
\hline 11 & $\begin{array}{l}\text { US20200299627A1 } \\
\text { United States }\end{array}$ & $\begin{array}{l}\text { Crosslinked hydrogel } \\
\text { compositions for } \\
\text { regulating states of } \\
\text { encapsulated } \\
\text { cancer cells }\end{array}$ & $\begin{array}{l}\text { Method of regulating } \\
\text { the state of cancer cells }\end{array}$ & $\begin{array}{l}\text { A system composed of a crosslinked } \\
\text { poly alkylene glycol based hydrogel, } \\
\text { systems comprising a number of cancer } \\
\text { cells in contact with the culture media } \\
\text { and encapsulated inside the hydrogel, } \\
\text { and the method of making and using } \\
\text { the same }\end{array}$ \\
\hline 12 & $\begin{array}{l}\text { JP2020514500A } \\
\text { Japan }\end{array}$ & $\begin{array}{l}\text { Antibacterial polymer } \\
\text { and antibacterial } \\
\text { hydrogel }\end{array}$ & $\begin{array}{c}\text { Antimicrobial } \\
\text { polymers and } \\
\text { antimicrobial hydrogels }\end{array}$ & $\begin{array}{l}\text { An antimicrobial hydrogel containing a } \\
\text { substituted C5-C15 alkyl; a } \\
\text { polyethyleneimine-alkyl-polyethylene } \\
\text { glycol methacrylate implant ratio } \\
\text { ranging from 1:1:1 to 1:20:20 and a } \\
\text { method of forming the same, providing } \\
\text { a device having a surface coating the } \\
\text { antimicrobial hydrogel as well }\end{array}$ \\
\hline 13 & $\begin{array}{l}\text { EP2801377B1 } \\
\text { European Patent } \\
\text { Office }\end{array}$ & $\begin{array}{l}\text { Hydrogel comprising } \\
\text { cells for local release of } \\
\text { growth factors to } \\
\text { mediate motor } \\
\text { recovery after stroke }\end{array}$ & $\begin{array}{l}\text { Hydrogel comprising } \\
\text { cells that provide a } \\
\text { sustained release of } \\
\text { brain derived } \\
\text { neurotrophic factor } \\
\text { (BDNF) for improving } \\
\text { recovery of a mammal } \\
\text { after cerebral ischemia }\end{array}$ & $\begin{array}{l}\text { Method of administering a } \\
\text { therapeutically effective amount of } \\
\text { BDNF to the infarct cavity in the } \\
\text { mammalian brain for the treatment of } \\
\text { cerebral ischemia }\end{array}$ \\
\hline 14 & $\begin{array}{l}\text { US20190282699A1 } \\
\text { United States }\end{array}$ & $\begin{array}{l}\text { Thiolated } \\
\text { hyaluronan-based } \\
\text { hydrogels crosslinked } \\
\text { using oxidized } \\
\text { glutathione }\end{array}$ & $\begin{array}{l}\text { Hydrogel comprising } \\
\text { the therapeutic agent, } \\
\text { carboxymethylated } \\
\text { hyaluronan and } \\
\text { thiolated gelatin }\end{array}$ & $\begin{array}{c}\text { Methods, compositions and kits linking } \\
\text { to hyaluronan based matrices with } \\
\text { oxidized glutathione as a } \\
\text { crosslinking agent }\end{array}$ \\
\hline
\end{tabular}


Table 2. Cont.

\begin{tabular}{|c|c|c|c|c|}
\hline S. No. & Patent No./Country & Title & Disease/Problem & Details \\
\hline 15 & $\begin{array}{c}\text { WO2021019562A2 } \\
\text { WIPO (PCT) }\end{array}$ & $\begin{array}{l}\text { Bioengineered } \\
\text { formulation, process } \\
\text { for preparing and im- } \\
\text { plementations thereof }\end{array}$ & $\begin{array}{l}\text { Bioengineered } \\
\text { formulation for } \\
\text { corneal applications }\end{array}$ & $\begin{array}{l}\text { A bioengineered formulation consisting } \\
\text { of a modified collagen peptide and } \\
\text { hyaluronic acid further, encompassing } \\
\text { stem cells/exosomes or } \\
\text { combinations therefrom }\end{array}$ \\
\hline 16 & $\begin{array}{l}\text { US10632070B2 } \\
\text { United States }\end{array}$ & $\begin{array}{c}\text { Hydrogel } \\
\text { toxin-absorbing or } \\
\text { binding nanoparticles }\end{array}$ & $\begin{array}{l}\text { For } \downarrow \text { or neutralizing } \\
\text { the effect of a toxin, or } \\
\text { for treating or } \\
\text { preventing an infection } \\
\text { by a microbe that } \\
\text { produces a toxin, in } \\
\text { a subject }\end{array}$ & $\begin{array}{l}\text { Polymeric hydrogel formulation infused } \\
\text { with a toxin-absorbing or } \\
\text { binding nanoparticle }\end{array}$ \\
\hline 17 & $\begin{array}{l}\text { CN105979969B } \\
\text { China }\end{array}$ & $\begin{array}{l}\text { Topical compositions } \\
\text { and methods of using } \\
\text { the same }\end{array}$ & $\begin{array}{l}\text { A topical } \\
\text { pharmaceutical } \\
\text { composition }\end{array}$ & $\begin{array}{l}\text { A topical composition comprises a nitric } \\
\text { oxide releasing active pharmaceutical } \\
\text { ingredient mixed with a hydrophilic } \\
\text { and a hydrophobic composition, in } \\
\text { which the nitric oxide releasing active } \\
\text { pharmaceutical ingredient encompasses } \\
\text { a diazeniumdiolate (A nitric oxide } \\
\text { releasing compound of a } \\
\text { functional group) }\end{array}$ \\
\hline
\end{tabular}

\begin{tabular}{|c|c|c|c|c|}
\hline 18 & $\begin{array}{c}\text { JP6309458B2 } \\
\text { Japan }\end{array}$ & $\begin{array}{l}\text { Silicone hydrogel } \\
\text { comprising } \\
\text { N-vinylamide and } \\
\text { hydroxyalkyl (meth) } \\
\text { acrylate or } \\
\text { (meth) acrylamide }\end{array}$ & $\begin{array}{l}\text { Silicone hydrogel soft } \\
\text { contact lenses provide } \\
\text { improved oxygen } \\
\text { permeability compared } \\
\text { to soft lenses made } \\
\text { from non-silicone } \\
\text { materials }\end{array}$ & $\begin{array}{c}\text { A silicone hydrogel comprising } \\
\text { n-vinylamide and hydroxyalkyl (meth) } \\
\text { acrylate/(meth) acrylamide }\end{array}$ \\
\hline 19 & $\begin{array}{l}\text { US10620456B2 } \\
\text { United States }\end{array}$ & $\begin{array}{l}\text { Increased stiffness } \\
\text { center optic in soft } \\
\text { contact lenses for } \\
\text { astigmatism correction }\end{array}$ & $\begin{array}{l}\text { Contact lenses for the } \\
\text { correction } \\
\text { of astigmatism }\end{array}$ & $\begin{array}{l}\text { Contact lenses having a higher stiffness } \\
\text { in the central optic zone for the } \\
\text { correction of astigmatic refractive errors } \\
\text { as well as possible higher order } \\
\text { aberrations created by corneal geometry }\end{array}$ \\
\hline 20 & $\begin{array}{c}\text { JP6143269B2 } \\
\text { Japan }\end{array}$ & $\begin{array}{l}\text { Self-assembled } \\
\text { composite ultra-small } \\
\text { peptide } \\
\text { polymer hydrogel }\end{array}$ & $\begin{array}{l}\text { Topical agents for } \\
\text { wound healing, as well } \\
\text { as for delivering } \\
\text { pharmaceuticals and } \\
\text { other bioactive } \\
\text { agents/components }\end{array}$ & $\begin{array}{l}\text { A method for fabricating composite } \\
\text { hydrogels, as implants /injectables that } \\
\text { encourage tissue regeneration and as } \\
\text { topical agents for wound healing to } \\
\text { deliver pharmaceuticals and other } \\
\text { bioactive agents components }\end{array}$ \\
\hline 21 & $\begin{array}{l}\text { US9937254B2 } \\
\text { United States }\end{array}$ & $\begin{array}{l}\text { Water-soluble } \\
\text { supramolecular } \\
\text { complexes }\end{array}$ & $\begin{array}{l}\text { The complexes are } \\
\text { useful in a variety of } \\
\text { pharmaceutical and } \\
\text { cosmetic products and } \\
\text { may be combined with } \\
\text { an effective amount of a } \\
\text { cosmetic, medicament, } \\
\text { or diagnostic in a solid } \\
\text { dosage form }\end{array}$ & $\begin{array}{c}\text { Water-soluble supramolecular } \\
\text { complexes formed when combined with } \\
\text { water, form a transparent } \\
\text { thermo-reversible hydrogel/solution } \\
\text { that may be repeatedly hydrated and } \\
\text { dehydrated for sparely soluble and } \\
\text { insoluble pharmaceutical agents, } \\
\text { exhibits } \uparrow \text { gelling efficiency, } \uparrow \text { solubility } \\
\text { and/or stability }\end{array}$ \\
\hline 22 & $\begin{array}{l}\text { EP2708224A1 } \\
\text { European Patent } \\
\text { Office }\end{array}$ & $\begin{array}{l}\text { Biocompatible } \\
\text { hydrogel polymer } \\
\text { formulations for the } \\
\text { controlled delivery } \\
\text { of biomolecules }\end{array}$ & $\begin{array}{l}\text { A biocompatible, } \\
\text { bioabsorbable hydrogel } \\
\text { polymer that releases } \\
\text { the therapeutic agent at } \\
\text { a target site, avoiding } \\
\text { systemic exposure in a } \\
\text { controlled delivery }\end{array}$ & $\begin{array}{l}\text { The kits including at least one } \\
\text { nucleophilic compound/monomer unit, } \\
\text { minimum one electrophilic } \\
\text { compound/monomer unit, and at least } \\
\text { one drug. Further, the therapeutic agent } \\
\text { such as a protein or other biomolecule is } \\
\text { capable of gelling in vivo }\end{array}$ \\
\hline
\end{tabular}


Table 2. Cont.

\begin{tabular}{|c|c|c|c|c|}
\hline S. No. & Patent No./Country & Title & Disease/Problem & Details \\
\hline 23 & $\begin{array}{c}\text { JP2017527422A } \\
\text { Japan }\end{array}$ & $\begin{array}{l}\text { Composite materials } \\
\text { for tissue repair }\end{array}$ & $\begin{array}{l}\text { Composite materials } \\
\text { and methods which } \\
\text { restore lost soft tissue } \\
\text { volume and promote } \\
\text { soft tissue regeneration }\end{array}$ & $\begin{array}{l}\text { A structural framework composite } \\
\text { having a polymeric fiber component } \\
\text { covalently bonded to a hydrogel } \\
\text { material possessing } \uparrow \text { properties }\end{array}$ \\
\hline 24 & $\begin{array}{l}\text { US20190343761A1 } \\
\text { United States }\end{array}$ & $\begin{array}{l}\text { Antibiotic formulations } \\
\text { for lower back pain }\end{array}$ & $\begin{array}{l}\text { Injectable, thermo } \\
\text { gelling hydrogel } \\
\text { formulations to relieve } \\
\text { and/or treat low } \\
\text { back pain }\end{array}$ & $\begin{array}{l}\text { A thermosensitive hydrogel, consisting } \\
\text { of an effective amount of an antibiotic, a } \\
\text { radio-contrast agent, and at least } 1 \\
\text { pharmaceutically acceptable excipient }\end{array}$ \\
\hline 25 & $\begin{array}{l}\text { US20170360912A1 } \\
\text { United States }\end{array}$ & $\begin{array}{l}\text { Chitosan-based } \\
\text { hydrogel and } \\
\text { applications thereof. }\end{array}$ & $\begin{array}{l}\text { Chitosan-based } \\
\text { hydrogel for medical } \\
\text { and cosmetic } \\
\text { treatments }\end{array}$ & $\begin{array}{l}\text { flowable formulation and becomes a gel } \\
\text { after a gelation time (depending on } \\
\text { temperature) just immediately after } \\
\text { preparation, containing chitosan, } 0.4 \mathrm{M} \\
\text { of sodium hydrogen carbonate (SHC), } \\
\text { and a weak base different from the SHC }\end{array}$ \\
\hline 26 & $\begin{array}{c}\text { US10842743B2 } \\
\text { United States }\end{array}$ & $\begin{array}{l}\text { Modified hyaluronic } \\
\text { acid hydrogels and } \\
\text { proteins for the } \\
\text { time-controlled release } \\
\text { of biologic agents }\end{array}$ & $\begin{array}{l}\text { Composition as a } \\
\text { liquid capable of in situ } \\
\text { formation of a } \\
\text { hyaluronic acid-based } \\
\text { hydrogel for treating a } \\
\text { subject suffering } \\
\text { from tumor(s) }\end{array}$ & $\begin{array}{l}\text { Discloses the hyaluronic acid-based } \\
\text { hydrogels, solutions for preparing same, } \\
\text { and methods relating to this. It includes } \\
\text { properties such as extended release, } \\
\text { self-resorption of drug, and/or } \downarrow \\
\text { degradation, denaturation, and/or } \\
\text { functional inactivation of active agents }\end{array}$ \\
\hline 27 & $\begin{array}{l}\text { US9211107B2 } \\
\text { United States }\end{array}$ & $\begin{array}{l}\text { Ruggedized ultrasound } \\
\text { hydrogel insert }\end{array}$ & $\begin{array}{l}\text { A ruggedized } \\
\text { hydrogelproduct } \\
\text { suitable for use in } \\
\text { medical applications } \\
\text { where sterile } \\
\text { components } \\
\text { are required }\end{array}$ & $\begin{array}{l}\text { It contains a gel component, water for } \\
\text { hydrating it, and minimum one free } \\
\text { radical absorber component that has the } \\
\text { capacity to absorb free radicals } \\
\text { produced during the sterilization of the } \\
\text { hydrogel through a high-energy } \\
\text { sterilization procedure and can survive } \\
\text { the effects of high-energy sterilization } \\
\text { procedures, without substantial } \\
\text { structural degradation }\end{array}$ \\
\hline 28 & $\begin{array}{l}\text { TWI558414B } \\
\text { Taiwan }\end{array}$ & $\begin{array}{l}\text { Thermosensitive } \\
\text { injectable hydrogel for } \\
\text { drug delivery }\end{array}$ & $\begin{array}{l}\text { Heat-sensitive } \\
\text { injectable hydrogels for } \\
\text { drug delivery for } \\
\text { delivering } \\
\text { anti-cancer drugs }\end{array}$ & $\begin{array}{l}\text { A heat-sensitive injectable hydrogel } \\
\text { system based on hyaluronic acid and a } \\
\text { copolymer of polyethylene oxide and } \\
\text { poly oxypropylene, (having a gel } \\
\text { formation temperature of } 30^{\circ} \mathrm{C} \text { to } \\
37^{\circ} \mathrm{C} \text { ), providing an efficient drug } \\
\text { delivery system that } \uparrow \text { the therapeutic } \\
\text { efficacy of the drug }\end{array}$ \\
\hline 29 & $\begin{array}{l}\text { JP6066237B2 } \\
\text { Japan }\end{array}$ & $\begin{array}{c}\text { Antibacterial } \\
\text { ophthalmic contact } \\
\text { lenses }\end{array}$ & $\begin{array}{c}\text { Antibacterial } \\
\text { ophthalmic devices } \\
\text { made of hydrogel and } \\
\text { epsilon polylysine } \\
(\varepsilon \text { PLL) }\end{array}$ & $\begin{array}{l}\text { It comprises a hydrogel and at least } 5 \mu \mathrm{g} \\
\varepsilon \text { PLL bonded non-covalently to the } \\
\text { hydrogel, the contact lens and the } \\
\text { packaging solutions }\end{array}$ \\
\hline 30 & $\begin{array}{l}\text { EP3151872B1 } \\
\text { European Patent } \\
\text { Office }\end{array}$ & Wound dressing & $\begin{array}{l}\text { A stimuli responsive } \\
\text { wound dressing } \\
\text { application against a } \\
\text { wound site of a human } \\
\text { or animal body }\end{array}$ & $\begin{array}{c}\text { A wound dressing containing } \\
\text { a lyophilized hyaluronic acid hydrogel } \\
\text { and } \\
\text { a number of implanted devices within } \\
\text { hydrogel, each device includes chitosan } \\
\text { and hypromellose where the } \\
\text { formulation absorbs water and/or } \\
\text { exudates and maintain a moist wound } \\
\text { site which encourages angiogenesis and } \\
\text { wound healing }\end{array}$ \\
\hline
\end{tabular}


Table 2. Cont.

\begin{tabular}{|c|c|c|c|c|}
\hline S. No. & Patent No./Country & Title & Disease/Problem & Details \\
\hline 31 & $\begin{array}{l}\text { EP3708167A1 } \\
\text { European Patent } \\
\text { Office }\end{array}$ & $\begin{array}{l}\text { Immunomodulating } \\
\text { treatments of } \\
\text { body cavities }\end{array}$ & $\begin{array}{l}\text { A combination } \\
\text { medicaments for use in } \\
\text { treatment of a cancer of } \\
\text { an internal body cavity } \\
\text { including urinary tract } \\
\text { cancer, meant for local } \\
\text { administration in a } \\
\text { thermo-reversible } \\
\text { hydrogel composition }\end{array}$ & $\begin{array}{l}\text { A biocompatible hydrogel composition } \\
\text { incorporating the combination of at } \\
\text { least } 2 \text { immunomodulatory agents, } \\
\text { where one or more of the therapeutic } \\
\text { agents are embedded inside, and slowly } \\
\text { released from it }\end{array}$ \\
\hline 32 & $\begin{array}{l}\text { WO2019221559A1 } \\
\text { WIPO (PCT) }\end{array}$ & $\begin{array}{l}\text { Microneedle adhesive } \\
\text { patch based on } \\
\text { hydrogel formulation }\end{array}$ & $\begin{array}{l}\text { A microneedle patch } \\
\text { that can be utilized for } \\
\text { transdermal drug } \\
\text { delivery to promote } \\
\text { wound regeneration } \\
\text { shows brilliant tissue } \\
\text { adhesion, biocompati- } \\
\text { bility, and biodegrad- } \\
\text { ability }\end{array}$ & $\begin{array}{l}\text { It comprises a 1st hydrogel layer with } \\
\text { mussel adhesive protein and hyaluronic } \\
\text { acid and 2nd hydrogel layer with silk } \\
\text { fibroin, and a method for } \\
\text { manufacturing it }\end{array}$ \\
\hline 33 & $\begin{array}{l}\text { WO2020036526A1 } \\
\text { WIPO (PCT) }\end{array}$ & $\begin{array}{l}\text { A biphasic hydrogel } \\
\text { formulation and } \\
\text { methods of production } \\
\text { and use thereof }\end{array}$ & $\begin{array}{l}\text { Creates an } \\
\text { environment that } \\
\text { relieves or encourages } \\
\text { the healing process for } \\
\text { the treatment of insect } \\
\text { bites, erythema, } \\
\text { pruritus, sunburn, acne, } \\
\text { dry skin or callus }\end{array}$ & $\begin{array}{l}\text { A hydrogel patch where a biphasic } \\
\text { formulation is organized that } \\
\text { encompassing a liquid layer externally } \\
\text { and an elastic hydrogel in which the } \\
\text { water formed on the surface of the } \\
\text { elastic gel is physically cooling the skin } \\
\text { by evaporation and give a 1st boost of } \\
\text { the drug directly when placing on } \\
\text { the skin }\end{array}$ \\
\hline 34 & $\begin{array}{l}\text { US20200246472A1 } \\
\text { United States }\end{array}$ & $\begin{array}{l}\text { Hydrogel-forming } \\
\text { composition for } \\
\text { controlled release }\end{array}$ & $\begin{array}{l}\text { Drug delivery systems } \\
\text { (injectable biogel) }\end{array}$ & $\begin{array}{l}\text { Peptide hydrogelators capable of } \\
\text { forming hydrogels as carriers of active } \\
\text { ingredients/biological materials and act } \\
\text { as sustained/controlled release systems }\end{array}$ \\
\hline 35 & $\begin{array}{l}\text { AU2015374022B2 } \\
\text { Australia }\end{array}$ & $\begin{array}{l}\text { Polyfunctional radical } \\
\text { scavenger hydrogel } \\
\text { formulation }\end{array}$ & $\begin{array}{l}\text { Providing extended } \\
\text { protection of the } \\
\text { extracellular space } \\
\text { within a wound site }\end{array}$ & $\begin{array}{l}\text { The polyfunctional radical scavenger } \\
\text { hydrogel formulation, A portion of the } \\
\text { 1st radical scavenger included with the } \\
\text { formulation and/or 2nd radical } \\
\text { scavenger included within the } \\
\text { formulation either in dissolved, } \\
\text { suspended and/or bonded to a polymer } \\
\text { of the hydrogel }\end{array}$ \\
\hline 36 & $\begin{array}{l}\text { US10471181B2 } \\
\text { United States }\end{array}$ & $\begin{array}{c}\text { Fiber-hydrogel } \\
\text { composite surgical } \\
\text { meshes for tissue repair }\end{array}$ & $\begin{array}{l}\text { A surgical scaffold } \\
\text { device for reducing } \\
\text { foreign body response, } \\
\text { managing tissue- } \\
\text { materials interface, and } \\
\text { improving the } \\
\text { integration of the } \\
\text { surgical mesh with the } \\
\text { surrounding tissue of } \\
\text { a subject }\end{array}$ & $\begin{array}{l}\text { It disclose a composition and methods } \\
\text { for a hydrogel/ nanofiber-hydrogel } \\
\text { composite integrated with a surgical } \\
\text { scaffold or mesh }\end{array}$ \\
\hline
\end{tabular}

Table 3. List of Clinical trials relating to various biomedical applications of hydrogel.

\begin{tabular}{|c|c|c|c|c|c|}
\hline Type of Hydrogel & Disease & Formulation & Study Outcome & Status & $\begin{array}{l}\text { Clinical Trial } \\
\text { Identifier }\end{array}$ \\
\hline Hydroxyethyl cellulose hydrogel & Knee pain by osteoarthritis & Injection & NA & On-going & NCT04061733 \\
\hline Polyacrylamide & Knee pain by osteoarthritis & Intra-articular injection & $\begin{array}{l}\text { Clinical examination } \\
\text { reported a transition from } \\
-7, \text { meaning worse to } 7, \\
\text { better on a scale of }-1 \text { to } 7 \text {. }\end{array}$ & Completed & NCT03060421 \\
\hline
\end{tabular}


Table 3. Cont.

\begin{tabular}{|c|c|c|c|c|c|}
\hline Type of Hydrogel & Disease & Formulation & Study Outcome & Status & $\begin{array}{l}\text { Clinical Trial } \\
\text { Identifier }\end{array}$ \\
\hline $\begin{array}{c}\text { Polyacrylamide hydrogel and } \\
\text { hyaluronic acid }\end{array}$ & Knee pain by osteoarthritis & Intra-articular injection & NA & On-going & NCT02763956 \\
\hline Polyacrylonitrile hydrogel & Degenerative disc disease & Intra-discal & NA & On-going & NCT02763956 \\
\hline Hydroxyethylcellulose hydrogel & Knee pain by osteoarthritis & Intra-articular injection & NA & On-going & NCT04061733 \\
\hline Extracellular matrix hydrogel & Heart failure & & & & \\
\hline Alginate hydrogel & Heart failure & $\begin{array}{l}\text { Intra-myocardial } \\
\text { injection }\end{array}$ & $\begin{array}{l}\text { Improved maximum } \\
\text { oxygen uptake }\end{array}$ & Completed & NCT01311791 \\
\hline Renal cells gelatin hydrogel & Kidney disease & Injection & $\begin{array}{l}\text { Improved levels of } \\
\text { creatinine, proteinuria, GFR }\end{array}$ & Completed & NCT02525263 \\
\hline Renal cells gelatin hydrogel & $\begin{array}{l}\text { Congenital chronic kidney } \\
\text { disease }\end{array}$ & Injection & NA & On-going & NCT04115345 \\
\hline $\begin{array}{l}\text { Human amniotic epithelial } \\
\text { cells hydrogel }\end{array}$ & Asherman's syndrome & Intra-uterine injection & NA & On-going & NCT03223454 \\
\hline Cardiac stem cells gelatin hydrogel & Ischemic cardiomyopathy & $\begin{array}{l}\text { Intra-myocardial } \\
\text { injection }\end{array}$ & $\begin{array}{c}\text { Improved ventricular } \\
\text { dysfunction }\end{array}$ & Completed & NCT00981006 \\
\hline Radiopaque Hydrogel & Pancreatic cancer & Injection & NA & On-going & NCT03307564 \\
\hline Biosentry Hydrogel & $\begin{array}{l}\text { Pneumothorax risk after } \\
\text { Lung biopsy procedures }\end{array}$ & Tract plug & NA & On-going & NCT02224924 \\
\hline TraceIT hydrogel & Oropharyngeal cancer & Injection & NA & On-going & NCT03713021 \\
\hline TraceIT hydrogel & Rectal cancer & Transperineal injection & NA & On-going & NCT03258541 \\
\hline SpaceOAR hydrogel (PEG) & $\begin{array}{l}\text { Prevention of radiation } \\
\text { exposure to rectum in } \\
\text { radiation therapy }\end{array}$ & Injection & $\begin{array}{l}\text { Reduced adverse effects and } \\
\text { limited radiation exposure } \\
\text { observed in subjects }\end{array}$ & Completed & NCT01538628 \\
\hline SpaceOAR hydrogel & $\begin{array}{l}\text { Image Guided Intensity } \\
\text { Modulated Radiotherapy for } \\
\text { prostate cancer }\end{array}$ & Injection & $\begin{array}{l}\text { Reduced rectal toxicity was } \\
\text { observed following } \\
\text { radiation therapy }\end{array}$ & Completed & NCT02212548 \\
\hline TracelT hydrogel & $\begin{array}{l}\text { Bladder cancer } \\
\text { radiation therapy }\end{array}$ & Injection & $\begin{array}{l}\text { Helped in locating bladder } \\
\text { tumor during } \\
\text { imaging process }\end{array}$ & Completed & NCT03125226 \\
\hline VentriGel & $\begin{array}{l}\text { Myocardial infarc- } \\
\text { tion/heart failure }\end{array}$ & $\begin{array}{l}\text { Trans-endocardial } \\
\text { injection }\end{array}$ & $\begin{array}{l}\text { Parameters such as ejection } \\
\text { fraction, end-diastolic } \\
\text { volume and end-systolic } \\
\text { volume were improved } \\
\text { in myocardial } \\
\text { infarction patients. }\end{array}$ & Completed & NCT02305602 \\
\hline $\begin{array}{l}\text { Gut Guarding Gel (alginate with } \\
\text { calcium lactate) }\end{array}$ & $\begin{array}{l}\text { Endoscopic Submucosal } \\
\text { Dissection }\end{array}$ & Sub-mucosal injection & $\begin{array}{l}\text { It enhanced the mucosa } \\
\text { formation and reduced } \\
\text { bleeding/tissue injury } \\
\text { following endoscopy }\end{array}$ & Completed & NCT03321396 \\
\hline Polyacrylamide hydrogel & urinary incontinence & Transurethral injection & $\begin{array}{c}\text { The bladder retention } \\
\text { volume was monitored and } \\
\text { successful voiding was } \\
\text { observed }\end{array}$ & Completed & NCT02776423 \\
\hline Polyacrylamide hydrogel and botox & urinary incontinence & Midurethral injection & $\begin{array}{l}\text { Micturitions per day } \\
\text { increased and relief from } \\
\text { urinary incontinence } \\
\text { observed }\end{array}$ & Completed & NCT02815046 \\
\hline Polyacrylamide hydrogel & Anal incontinence & Transanal injection & $\begin{array}{c}\text { Reduced Wexner scores were } \\
\text { observed after treatment }\end{array}$ & Completed & NCT02550899 \\
\hline $\begin{array}{l}\text { OTX-TKI (polyethylene glycol } \\
\text { hydrogel with tyrosine } \\
\text { kinase inhibitor) }\end{array}$ & $\begin{array}{l}\text { Age-related Macular } \\
\text { Degeneration }\end{array}$ & Intravitreal injection & NA & On-going & NCT03630315 \\
\hline
\end{tabular}

\subsection{Cosmetics Applications}

Skin is the largest organ that acts as a physical and chemical barrier and protects the body. From the cosmetic point of view, skin is responsible for external appearance and is usually treated with cosmetic preparations. Skin condition depends on several factors, among which hydration of the skin is critical in maintaining its appearance and texture [35]. When the skin barrier is damaged, either due to climatic conditions and pollution or natural ageing (the genetic factors and photo-aging) it demands reconditioning. For this purpose, a range of moisturizers to re-establish the skin properties and barrier functions can be used. Stratum corneum (upper layer of the skin) can be rehydrated by three mechanisms 
such as by using humectants, occlusive and hydrophilic matrices. Nowadays, hydrogel is widely exploited in the cosmetics industries due to properties such as high water retention, biocompatibility, elasticity and softness [36]. These are mainly employed for skin hydration, wrinkles, pigmentation, cellulite and ageing, etc. Cosmetically these are mainly applied topically on skin, hair, and also used in oral care. Bioadhesive hydrogels are used for skincare purposes as they have advantages, such as long residence times on the site of application which ultimately reduces administration frequency. Acrylate-based hydrogel, due to its superabsorbent properties, is highly exploited to prepare hygiene products that can absorb fluids and keep moisture away from the skin, preventing diaper rash, promoting hygiene, and providing comfort.

\subsection{Wound Dressings}

Human skin has a unique potential for self-regeneration, owing to this, skin defects can heal spontaneously but if the defect is measuring more than a certain diameter, then it requires skin transplantation. Moreover, the wound healing process is impaired in some patients due to various conditions that lead to chronic wounds, which ultimately result in drastic conditions or even mortality [37]. Hydrogels are the most promising approach in wound healing amongst various wound dressings polymeric materials such as gauzes, hydrocolloids, gels, hydrogels, etc. Hydrogels act as an ideal wound dressing for the management of wounds as they can provide a moist milieu in the wound site, prevent infection, help in the removal of wound exudates and mimic the native skin microenvironment for tissue regeneration. In addition, hydrogels have unique features such as biocompatibility, softness and malleability which make them fit for the purpose. Polysaccharides based on hydrogel (cellulose, dextran, agarose) have greater water absorption capability, making them ideal candidates in wound healing [38]. However anti-bacterial and anti-inflammatory hydrogels have a good impact in wound healing [39-41].

\subsection{Drug Delivery}

Drug delivery can be defined as the process of administering a drug to a human or animal to achieve a desired therapeutic effect at an effective rate at the targeted site [42]. Delivery of the drug in a controlled manner at the particular target for an extended period is another important requirement of a good delivery system. Hydrogels, due to their threedimensional release the drug in a controlled manner, especially for hydrophilic moieties. The porosity of the hydrogel further supports the sustained action of the drug [43].It also has a great potential for application via different routes. When the hydrogel is transplanted and injected or into an organism, it can maintain an embedded drug's effective and controlled release into body fluids [44]. The hydrogel can improve the therapeutic effects of many lipophilic drugs that are restricted due to various problems, including poor solubility, poor dispersion, poor dissolution, low bioavailability, lack of uniformity, and lack of in vivo stability, etc. However, its fabrication is a difficult task and can be improved by the amalgamation of molecules having the ability to form inclusion complexes by incorporating the hydrophobic moieties [2,45]. Hydrogels can also be used as a carrier for biological macromolecular drugs, polysaccharide substances and genes, etc., without affecting the release kinetics. It follows different drug release models such as swelling controlled, diffusion-controlled and chemically controlled to release the medicaments in a controlled manner that act as release drives for the system [46].

Among diverse delivery systems injectable hydrogels are one of the extensively investigated scaffolds or therapeutic agents carriers in the area of disease treatment.

\section{Injectable Hydrogels for Disease Treatment}

Due to numerous advantages of the hydrogel systems, they have been considered suitable scaffolds or active ingredients carriers [47]. However, it requires an invasive surgical procedure for implanting pre-formed hydrogels at a specific site in the body associated with pain and discomfort in the patients, that leads to decreased patient compliance and 
increased treatment costs; thus, limiting their clinical uses. Injectable hydrogels can overcome such disadvantages in biomedical applications with minimal invasiveness into target sites. These hydrogels can be exploited as a promising and efficacious material system for many applications in the medical field, such as treatment for cancers, inflammatory and infectious diseases; delivery of drugs, cells, and bioactive molecules and applications in the repair and regeneration of tissues such as skin, muscles, bone and cartilage [48]. Table 4 enlists various injectable hydrogels with biomedical applications.

Injectable hydrogels involve the sol-gel transition produced by cross-linking. For solutions of a polymer/monomer with therapeutic agents that have low viscosity when administrated to a desired site in the body, a hydrogel loaded with a therapeutic agent can be formed by crosslinking reaction that has a comparatively higher viscosity, called a gel state. The polymers in the hydrogel form a cross-link by chemical or physical interactions which are responsible for phase transition from solution to gel state. The solgel phase transition is sensitive to changes in $\mathrm{pH}$, temperature, light, enzymes, ultrasounds, etc. [49-51]. Physical crosslinking occurs due to electrostatic ionic and hydrogen bond interactions, $\pi$-interactions, hydrophobic interactions, Van der Waals forces, etc. In contrast, chemical crosslinking occurs due to Schiff base reactions, Diels-Alder reactions, photo polymerizations, Michael additions, enzyme-mediations, etc.

Recently, the delivery of chemotherapeutics in the form of injectable hydrogels became a promising alternative for cancer/tumor management with biocompatibility, enhanced drug loading, prolonged and controlled drug release, with explicit stimuli sensitivity. Injectable hydrogel can be used as a flexible tool to reach some areas that cannot be easily touched by surgery. Furthermore, hydrogel can be used as a platform for tissue repair (tissue engineering [52-54]) and prevent postoperative tumor recurrence. Injectable biodegradable hydrogels that can form gels in situ have been widely utilized for biomedical applications. Additionally, these hydrogels can be biofunctionalized by targeting moieties that have an affinity for overexpressed and/or unique tumor cell markers for targeted drug delivery applications [55].

Hydrogels have been used as a substitute for conventional cancer therapy, which is frequently associated with various factors such as unwanted toxicity to normal tissues, gigantic tissue loss, and unanticipated recurrence during or after the treatment. Localized drug delivery techniques (such as hydrogels [56], liposomes, nano/microparticles [57-59], micelles $[8,60]$ offer localized sustained release of the chemotherapeutic. It results in increased efficacy of the treatment with minimal tissue toxicity by circumventing systemic circulation of the chemotherapeutic agents. They further facilitate high drug loading, improve solubility, and sustain drug release at the desire treatment location. Several systems have been explored for this purpose. The following Figure 6 depicts an overview of injectable hydrogel.

Table 4. List of various injectable hydrogels having biomedical applications.

\begin{tabular}{|c|c|c|c|c|c|c|}
\hline Hydrogel & Active Ingredient & Type of Disease & In Vitro Cell Line & In Vivo Model & Conclusion & Reference \\
\hline $\begin{array}{l}\text { Thermosensitive } \\
\text { chitosan-based }\end{array}$ & Disulfiram(DSF) & Cancer & $\begin{array}{c}\text { Human HCC cell } \\
\text { lines (SMMC-7721 } \\
\text { cells) }\end{array}$ & - & $\begin{array}{l}\text { A novel injectable sustained } \\
\text { formulation for anticancer } \\
\text { drugs aimed at the delivery of } \\
\text { DSF for long-term } \\
\text { cancer treatment }\end{array}$ & [61] \\
\hline $\begin{array}{c}\text { Dual thermo-and } \\
\text { pH-sensitive injectable } \\
\text { hydrogels of } \\
\text { chitosan/(poly(N- } \\
\text { isopropylacrylamide-co- } \\
\text { itaconic acid) }\end{array}$ & Doxorubicin & Breast cancer & MCF-7 cells & - & $\begin{array}{l}\text { Cytocompatible and exert } \\
\text { no/negligible cytotoxicity on } \\
\text { MCF-7 cells and has the } \\
\text { potential for local therapy of } \\
\text { breast cancer }\end{array}$ & [62] \\
\hline $\begin{array}{l}\text { pH-sensitive poly(lactic } \\
\text { acid-co-glycolic } \\
\text { acid)- } b \text {-poly(ethylene } \\
\text { glycol)- } b \text {-poly(lactic } \\
\text { acid-co-glycolic acid) } \\
\text { (PLGA-PEG-PLGA) } \\
\text { triblock copolymers }\end{array}$ & Herceptin & Breast cancer & - & $\begin{array}{l}\text { SK-BR-3 tumor } \\
\text { bearing mice }\end{array}$ & $\begin{array}{l}\text { Great potential for preventing } \\
\text { the relapse of HER } 2+\text { breast } \\
\text { tumors after breast-conserving } \\
\text { surgery with } \uparrow \text { therapeutic } \\
\text { efficacy, } \downarrow \text { side effects and } \uparrow \\
\text { patient compliance }\end{array}$ & [63] \\
\hline
\end{tabular}


Table 4. Cont.

\begin{tabular}{|c|c|c|c|c|c|c|}
\hline Hydrogel & Active Ingredient & Type of Disease & In Vitro Cell Line & In Vivo Model & Conclusion & Reference \\
\hline $\begin{array}{l}\text { pH-sensitive injectable- } \\
\text { polysaccharide-based } \\
\text { self-healing hydrogels }\end{array}$ & Doxorubicin & $\begin{array}{l}\text { Hepatocellular } \\
\text { carcinoma }\end{array}$ & $\begin{array}{l}\text { HepG2(release of } \\
\text { drug from hydrogel) } \\
\text { L929 cells } \\
\text { (Cytotoxicity test of } \\
\text { the hydrogel) }\end{array}$ & - & $\begin{array}{l}\text { Self-healing property with high } \\
\text { drug-loading ratio could } \\
\text { prolong their lifetime during } \\
\text { implantation and provide the } \\
\text { benefit of nominally } \\
\text { invasive surgery }\end{array}$ & [64] \\
\hline $\begin{array}{c}\text { Dual } \mathrm{pH} \text { - and } \\
\text { temperature-responsive } \\
\text { physically crosslinked } \\
\text { injectable hydrogel }\end{array}$ & Cancer & $\begin{array}{c}\text { Oncolytic } \\
\text { adenoviruses }\end{array}$ & - & $\begin{array}{l}\text { Human xenograft } \\
\text { tumor models }\end{array}$ & $\begin{array}{l}\text { Exhibited } \uparrow \text { and long-term } \\
\text { antitumor therapeutic effects in } \\
\text { tumor models and might have } \\
\text { potential for long-term } \\
\text { cancer treatment }\end{array}$ & [65] \\
\hline $\begin{array}{c}\text { Novel palladium } \\
\text { nanosheet (Pd } \\
\text { NS)-based chemo- } \\
\text { photothermalhydrogel } \\
\text { (Pd Gel) }\end{array}$ & $\begin{array}{l}\text { Palladium and } \\
\text { doxorubicin }\end{array}$ & Cancer & - & Mouse & $\begin{array}{l}\text { A novel anticancer strategy that } \\
\text { allows the release of } \\
\text { doxorubicin more precisely, } \\
\text { eliminate tumor more } \\
\text { efficiently and inhibit tumor } \\
\text { metastasis more persistently }\end{array}$ & {$[66]$} \\
\hline $\begin{array}{c}\text { ABA triblock } \\
\text { copolymers of vitamin } \\
\text { D-functionalized } \\
\text { polycarbonate and } \\
\text { poly(ethylene glycol), } \\
\text { that is, VDm-PEG-VDm } \\
\text { were synthesized and } \\
\text { employed to form } \\
\text { physically crosslinked } \\
\text { injectable hydrogels }\end{array}$ & $\begin{array}{l}\text { Bevacizumab; } \\
\text { Avastin }\end{array}$ & Cancer & & $\begin{array}{c}\text { HCT116 } \\
\text { xenograft mouse } \\
\text { models }\end{array}$ & $\begin{array}{l}\text { Injection of the hydrogel was } \\
\text { effective to show antimetastatic } \\
\text { activity as that of } 4 \times \text { weekly } \\
\text { injections of Avastin thus } \downarrow \text { the } \\
\text { injection frequency and may } \uparrow \\
\text { patient compliance to treat } \\
\text { metastatic cancer }\end{array}$ & [67] \\
\hline $\begin{array}{l}\text { pH-responsive injectable } \\
\text { hydrogels made of a } \\
\text { supramolecular } \\
\text { cross-link network }\end{array}$ & doxorubicin & Cancer & $\begin{array}{l}\text { L929 mouse } \\
\text { fibroblasts }\end{array}$ & - & $\begin{array}{c}\text { Showed biocompatibility, } \\
\text { controlled release profiles and } \\
\text { tunable properties which show } \\
\text { a } \uparrow \text { potential as a drug-releasing } \\
\text { material for localized } \\
\text { treatments }\end{array}$ & [68] \\
\hline $\begin{array}{l}\text { Triblock Copolymers } \\
\text { of Vitamin } \\
\text { E-Functionalized } \\
\text { Polycarbonate and } \\
\text { Poly(ethylene glycol) }\end{array}$ & Herceptin & Breast cancer & $\begin{array}{l}\text { Human breast } \\
\text { cancer cell lines } \\
\text { (antitumor } \\
\text { specificity } \\
\text { and efficacy) }\end{array}$ & $\begin{array}{l}\text { BT474 tumor- } \\
\text { bearing mice- } \\
\text { (biocompatibility } \\
\text { and biodegrad- } \\
\text { ability) }\end{array}$ & $\begin{array}{c}\uparrow \text { potential for use in } \\
\text { subcutaneous and sustained } \\
\text { delivery of antibodies to } \uparrow \\
\text { therapeutic efficacy and /or } \uparrow \\
\text { patient compliance as } \\
\text { compared to intravenous and } \\
\text { subcutaneous delivery of } \\
\text { Herceptin in solution form }\end{array}$ & [69] \\
\hline $\begin{array}{l}\text { pH-responsive injectable } \\
\text { hydrogels with mucosal } \\
\text { adhesiveness based on } \\
\text { chitosan-grafted- } \\
\text { dihydrocaffeic acid and } \\
\text { oxidized pullulan }\end{array}$ & Doxorubicin & Colon tumor & $\begin{array}{l}\text { Colon tumor cells } \\
\text { (HCT116 cells) }\end{array}$ & - & $\begin{array}{l}\text { Showed good drug release, } \\
\text { effectively killing colon tumor } \\
\text { cells, ideal candidates for } \\
\text { development of colon cancer } \\
\text { drug delivery carriers } \\
\text { /mucoadhesive drug } \\
\text { delivery systems }\end{array}$ & [70] \\
\hline $\begin{array}{l}\text { Alginate hydrogel } \\
\text { system }\end{array}$ & $\begin{array}{l}\text { Angiogenesis with } \\
\text { vascular endothelial } \\
\text { growth factor } \\
\text { (VEGF) }\end{array}$ & $\begin{array}{c}\text { Cardiovascular } \\
\text { diseases }\end{array}$ & $\begin{array}{l}\text { Human } \\
\text { microvascular } \\
\text { dermal endothe- } \\
\text { lial cells }\end{array}$ & & $\begin{array}{l}\text { Act as a new generation of } \\
\text { therapeutic delivery vehicle by } \\
\text { combining long-term in vivo } \\
\text { therapeutic advantages with } \\
\text { minimal invasion to treat } \\
\text { cardiovascular diseases }\end{array}$ & [71] \\
\hline $\begin{array}{c}\text { Dual-responsive (pH } \\
\text { and ROS) injectable } \\
\text { hydrogels encapsulating } \\
\text { drug-loaded micelles }\end{array}$ & $\begin{array}{c}\text { Amikacin, } \\
\text { andNaproxen }\end{array}$ & Wound healing & & SD male rats & $\begin{array}{l}\text { Possess good biocompatibility } \\
\text { with efficient antibacterial and } \\
\text { anti-inflammatory action, } \uparrow \text { the } \\
\text { healing process and promising } \\
\text { to be applied topically against } \\
\text { various microbial infections }\end{array}$ & [72] \\
\hline $\begin{array}{l}\text { Alginate-chitosan } \\
\text { hydrogels }\end{array}$ & $\begin{array}{c}\text { IgG model } \\
\text { antibodies and Fab } \\
\text { antibody fragments }\end{array}$ & $\begin{array}{l}\text { Applications in } \\
\text { drug delivery } \\
\text { and regenera- } \\
\text { tive medicine }\end{array}$ & - & - & $\begin{array}{l}\text { Offers controlled delivery of } \\
\text { antibodies and antibody } \\
\text { fragments and will be } \\
\text { promising formulation for } \\
\text { several applications in drug } \\
\text { delivery and } \\
\text { regenerative medicine }\end{array}$ & [73] \\
\hline $\begin{array}{l}\text { Dopamine-based and } \\
\text { polydopamine } \\
\text { crosslinked injectable } \\
\text { hydrogels }\end{array}$ & $\begin{array}{l}\text { Dopamine and } \\
\text { metronidazole }\end{array}$ & $\begin{array}{l}\text { Parkinson's } \\
\text { disease }\end{array}$ & - & $\begin{array}{l}\text { mouse L929 } \\
\text { fibroblast cells }\end{array}$ & $\begin{array}{l}\text { Can be used as long-term, } \\
\text { localized, sustained release } \\
\text { injectable system for dopamine } \\
\text { as well as anti-inflammatory } \\
\text { drugs to treat Parkinson }\end{array}$ & {$[74]$} \\
\hline $\begin{array}{l}\text { Covalently crosslinked } \\
\text { composite hydrogel } \\
\text { embedded with } \\
\text { microspheres }\end{array}$ & & $\begin{array}{l}\text { Soft tissue } \\
\text { engineering }\end{array}$ & - & - & $\begin{array}{l}\text { Can be exploited as a potential } \\
\text { opportunity to use this } \\
\text { injectable composite gel } \\
\text { scaffold in protein delivery and } \\
\text { soft tissue } \\
\text { engineering applications }\end{array}$ & [75] \\
\hline
\end{tabular}


Table 4. Cont.

\begin{tabular}{|c|c|c|c|c|c|c|}
\hline Hydrogel & Active Ingredient & Type of Disease & In Vitro Cell Line & In Vivo Model & Conclusion & Reference \\
\hline $\begin{array}{l}\text { Gelatin-hydroxyphenyl } \\
\text { propionic acid } \\
\text { (Gtn-HPA) and } \\
\text { hyaluronic } \\
\text { acid-tyramine } \\
\text { (HA-Tyr)-based } \\
\text { hydrogels } \\
\end{array}$ & $\begin{array}{l}\text { Human epidermal } \\
\text { growth factor } \\
\text { (hEGF) }\end{array}$ & $\begin{array}{l}\text { Ophthalmic } \\
\text { applications }\end{array}$ & & & $\begin{array}{l}\text { Hydrodynamic model, giving a } \\
\text { normalized diffusion and } \\
\text { release of hEGF and provide } \\
\text { the most suitable explanation } \\
\text { for the measured solute } \\
\text { diffusion coefficient }\end{array}$ & [76] \\
\hline Porous alginate gels & Peptide antigen & Immunotherapies & - & $\begin{array}{l}\text { Nonobese } \\
\text { diabetic mouse } \\
\text { model of type } \\
1 \text { diabetes }\end{array}$ & $\begin{array}{l}\text { A noninflammatory biomaterial } \\
\text { system can generate } \\
\text { antigen-specific, that may } \\
\text { enable the development of new } \\
\text { therapies to treat transplant } \\
\text { rejection/autoimmune diseases }\end{array}$ & [77] \\
\hline $\begin{array}{l}\text { Self-healing injectable } \\
\text { micelle/hydrogel } \\
\text { composites quaternized } \\
\text { chitosan (QCS) solution } \\
\text { and benzaldehyde- } \\
\text { terminated poly(ethylene } \\
\text { oxide)- } b \text {-poly(propylene } \\
\text { oxide)- } b \text {-poly(ethylene } \\
\text { oxide) (PEO } \text { PE- }_{\text {-PPO }} \text { - } b \text { - } \\
\text { PEO99, Pluronic }{ }^{\circledR} \text { F127 } \\
\text { (PF127)) (PF127-CHO) } \\
\text { solution }\end{array}$ & Curcumin & $\begin{array}{l}\text { Wound dressing } \\
\text { for joints skin } \\
\text { wound healing }\end{array}$ & & $\begin{array}{l}\text { Female Kunming } \\
\text { mice }\end{array}$ & $\begin{array}{l}\text { Self-healing antibacterial } \\
\text { adhesive hydrogels with good } \\
\text { mechanical property offer } \\
\text { significant promise as dressing } \\
\text { materials for joints skin } \\
\text { wound healing }\end{array}$ & [78] \\
\hline $\begin{array}{l}\text { Alginate-gelatin } \\
\text { injectable hydrogel }\end{array}$ & $\begin{array}{l}\text { Oligochitosan } \\
\text { coated cerium oxide } \\
\text { nanoparticles }\end{array}$ & $\begin{array}{l}\text { Age-related } \\
\text { macular } \\
\text { degeneration }\end{array}$ & $\begin{array}{l}\text { Human retinal } \\
\text { pigment } \\
\text { epithlium-19 } \\
\text { (ARPE-19) and } \\
\text { umbilical } \\
\text { endothelium }\end{array}$ & - & $\begin{array}{c}\text { Biocompatible and have } \uparrow \\
\text { potential in protecting cells } \\
\text { from angiogenesis, apoptosis, } \\
\text { and production of } \\
\text { proinflammatory cytokines } \\
\text { with controlled drug release }\end{array}$ & [79] \\
\hline $\begin{array}{l}\text { Decellularized injectable } \\
\text { cardiac and skeletal } \\
\text { muscle extracellular } \\
\text { matrix hydrogel }\end{array}$ & - & $\begin{array}{l}\text { Potential } \\
\text { scaffolds } \\
\text { for tissue } \\
\text { regeneration } \\
\text { and/or repair } \\
\text { for treating } \\
\text { myocardial } \\
\text { infarction, heart } \\
\text { failure and } \\
\text { peripheral } \\
\text { artery disease }\end{array}$ & - & - & $\begin{array}{c}\text { Tissue specific biomaterial } \\
\text { therapies with } \\
\text { minimal invasion }\end{array}$ & [80] \\
\hline $\begin{array}{l}\text { Polysaccharide-based } \\
\text { hydrogels(N- } \\
\text { carboxyethyl chitosan } \\
\text { and oxidized } \\
\text { sodium alginate) }\end{array}$ & $\begin{array}{l}\text { Neural stem } \\
\text { cells delivery }\end{array}$ & $\begin{array}{l}\text { Neurological } \\
\text { disorders }\end{array}$ & Neural stem cells & - & $\begin{array}{l}\text { Neural stem cells } \\
\text { transplantation and } \\
\text { management of } \\
\text { neurological diseases }\end{array}$ & [81] \\
\hline $\begin{array}{c}\text { Non-degradable } \\
\text { dendritic polyglycerol } \\
\text { sulfate (dPGS) hydrogel }\end{array}$ & $\begin{array}{c}\text { Dendritic } \\
\text { polyglycerol sulfate }\end{array}$ & Osteoarthritis & - & - & $\begin{array}{l}\text { Formulation having good } \\
\text { viscoelastic properties and has } \\
\text { the benefit of being much less } \\
\text { easily displaced from its } \\
\text { injection site }\end{array}$ & [82] \\
\hline $\begin{array}{l}\text { Conductive anti-oxidant } \\
\text { hydrogels (N- } \\
\text { carboxyethyl chitosan } \\
\text { and oxidized hyaluronic } \\
\text { acid-graft- } \\
\text { aniline tetramer }\end{array}$ & Amoxicillin & Wound dressing & $\begin{array}{c}\mathrm{C} 2 \mathrm{C} 12 \\
\text { myoblast cells } \\
\text { (Cytocompatibility) } \\
\text { Escherichia coli and } \\
\text { Staphylococcus au- } \\
\text { reus (Antibacte- } \\
\text { rial activity) }\end{array}$ & $\begin{array}{l}\text { Male Kunming } \\
\text { mice }\end{array}$ & $\begin{array}{l}\text { Have good antibacterial, } \\
\text { biodegradation, electroactive } \\
\text { and free radical scavenging } \\
\text { property to efficiently prevent } \\
\text { the wound infection and can be } \\
\text { designed as an electroactive } \\
\text { injectable hydrogel with } \\
\text { promising applications }\end{array}$ & [83] \\
\hline $\begin{array}{l}\text { Injectable poly(ethylene } \\
\text { glycol) (PEG)- } \\
\text { gelatin hydrogel }\end{array}$ & $\begin{array}{l}\text { Murine } \\
\text { adipose-derived } \\
\text { stem cells }\end{array}$ & $\begin{array}{l}\text { Wound Healing } \\
\text { and tissue } \\
\text { regeneration }\end{array}$ & - & $\begin{array}{l}\text { Murine wound } \\
\text { healing model }\end{array}$ & $\begin{array}{l}\text { Significantly } \uparrow \text { cell retention, } \uparrow \\
\text { angiogenesis, and } \uparrow \text { wound } \\
\text { closure and can be used for } \\
\text { regulating stem cell behaviors } \\
\text { in } 3 D \text { culture, delivering cells } \\
\text { for wound healing and other } \\
\text { tissue regeneration applications }\end{array}$ & [84] \\
\hline $\begin{array}{l}\text { Polyplex Micelle-Loaded } \\
\text { Injectable Hydrogels }\end{array}$ & MicroRNA-29 & $\begin{array}{l}\text { Intervertebral } \\
\text { disc degenera- } \\
\text { tion(IDD) }\end{array}$ & & $\begin{array}{l}\text { Rabbits (thera- } \\
\text { peutic efficacy } \\
\text { on fibrosis } \\
\text { Inhibition) } \\
\text { Sprague-Dawley } \\
\text { rats (In vivo } \\
\text { delivery analysis) }\end{array}$ & $\begin{array}{l}\text { Successfully stop the expression } \\
\text { of matrix metalloproteinases, } \\
\text { prevent the fibrosis process and } \\
\text { reverse IDD in animal models }\end{array}$ & [85] \\
\hline
\end{tabular}


Table 4. Cont.

\begin{tabular}{|c|c|c|c|c|c|c|}
\hline Hydrogel & Active Ingredient & Type of Disease & In Vitro Cell Line & In Vivo Model & Conclusion & Reference \\
\hline $\begin{array}{c}\text { Collagen-chitosan-based } \\
\text { hydrogel }\end{array}$ & $\begin{array}{c}\text { Thymosin } \beta 4,(\mathrm{a} \\
43 \text {-amino } \\
\text { acid peptide) }\end{array}$ & $\begin{array}{l}\text { Myocardial } \\
\text { Infarction }\end{array}$ & $\begin{array}{l}\text { Monolayers of } \\
\text { BHK-21 }\end{array}$ & & $\begin{array}{c}\text { Stimulate angiogenesis and } \\
\text { epicardial heart cell migration } \\
\text { can be considered as a carrier of } \\
\text { other negatively charged active } \\
\text { biomolecules and thus shows } \\
\text { numerous applications }\end{array}$ & [86] \\
\hline Chitosan hydrogel & $\begin{array}{l}\text { Human } \\
\text { placenta-derived } \\
\text { mesenchymal stem } \\
\text { cell -derived } \\
\text { exosomes }\end{array}$ & $\begin{array}{l}\text { Hindlimb } \\
\text { Ischemia }\end{array}$ & - & Murine model & $\begin{array}{l}\text { Can } \uparrow \text { the retention and stability } \\
\text { of exosomes and further } \uparrow \text { the } \\
\text { therapeutic effects that may } \\
\text { facilitate the development of } \\
\text { easy and effective approaches } \\
\text { for assessing and enhancing the } \\
\text { therapeutic effects of stem } \\
\text { cell-derived exosomes }\end{array}$ & [87] \\
\hline $\begin{array}{c}\text { Sustained release, } \\
\text { thermosensitive } \\
\text { polymeric [poly(lactic } \\
\text { acid-co-glycolic } \\
\text { acid)-poly(ethylene } \\
\text { glycol)-poly(lactic } \\
\text { acid-co-glycolic acid) } \\
\text { (PLGA-PEG- } \\
\text { PLGA)]hydrogel }\end{array}$ & Avastin $^{\circledR}$ & $\begin{array}{l}\text { Posterior segment } \\
\text { disorders }\end{array}$ & - & Rat & $\begin{array}{l}\text { A promising candidate for } \\
\text { ocular drug delivery of } \\
\text { Avastin }{ }^{\circledR} \text { through } \\
\text { intravitreal injection }\end{array}$ & [88] \\
\hline $\begin{array}{l}\text { Catheter-injectable } \\
\text { hydrogel utilizing a } \\
\text { polymer-nanoparticle } \\
\text { crosslinking mechanism }\end{array}$ & - & $\begin{array}{l}\text { Various } \\
\text { therapeutic } \\
\text { applications }\end{array}$ & & Wistar rats & $\begin{array}{l}\text { Biocompatible, cell-signaling } \\
\text { and can be differentially } \\
\text { released with distinct elution } \\
\text { profiles, allowing precise } \\
\text { control over drug delivery }\end{array}$ & [89] \\
\hline $\begin{array}{l}\text { Self-healing hydrogel } \\
\text { based on chondroitin } \\
\text { sulfate multiple } \\
\text { aldehyde and } \\
\text { N-succinyl-chitosan }\end{array}$ & $\begin{array}{l}\text { Cells encapsulated } \\
\text { in the hydrogel }\end{array}$ & $\begin{array}{l}\text { Cell carrier and } \\
\text { in tissue } \\
\text { engineering }\end{array}$ & & Rat model & $\begin{array}{l}\text { Shows biodegradability, } \\
\text { produced } \downarrow \text { inflammatory } \\
\text { response and having potential } \\
\text { application as a cell carrier and } \\
\text { in tissue engineering. }\end{array}$ & [90] \\
\hline $\begin{array}{c}\text { Physiological } \\
\text { temperature-responsive } \\
\text { controllable } \\
\text { NO-releasing redox } \\
\text { injectable hydrogel }\end{array}$ & Nitric oxide(NO) & $\begin{array}{l}\text { Cardiovascular } \\
\text { diseases }\end{array}$ & - & Mice & $\begin{array}{l}\text { Significantly } \uparrow \text { the angiogenesis } \\
\text { and new blood vessels } \\
\text { formation by regulating the } \\
\text { sustained release of NO and } \\
\text { redox equilibrium in animal } \\
\text { model. It has a } \uparrow \text { potential in } \\
\text { preventing and } \\
\text { treating diseases }\end{array}$ & [91] \\
\hline
\end{tabular}

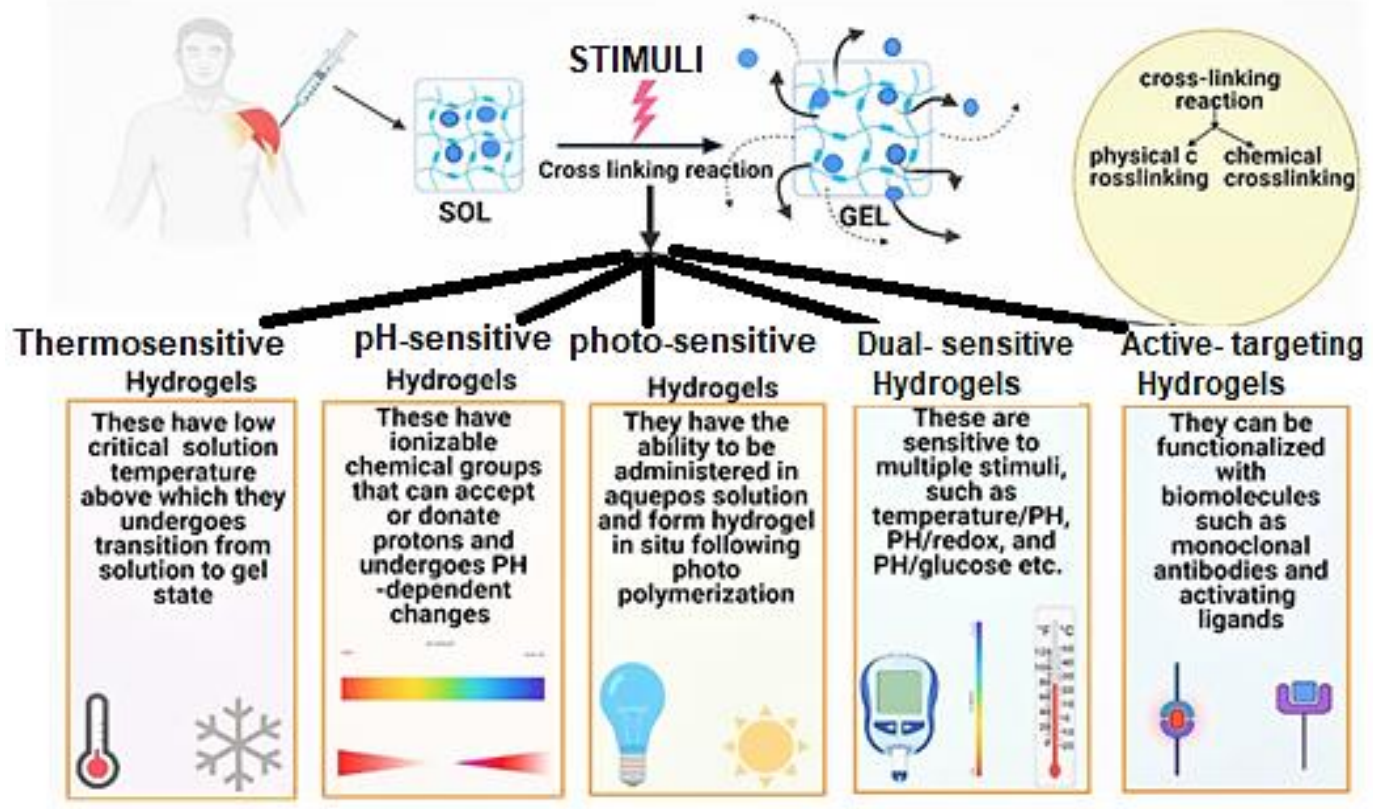

Figure 6. An overview of various aspects of injectable hydrogels. 


\subsection{Tissue Engineering and Regenerative Medicine}

Tissue engineering is a biomedical engineering discipline that refers to the practice of combining biologically active molecules, cells, and scaffolds into functional tissues. The main objective of tissue engineering is to accumulate biological substitutes that restore, repair, maintain, or improve injured tissues or whole organs. The scaffold resembles the extracellular matrix composed of porous structure responsible for supply of nutrients, cell growth and waste removal and thus aids tissue regeneration. In addition, the scaffolds should possess the desired quality attributes such as biocompatibility, biodegradability, mechanical strength and the ability to be sterilized. These characteristics are necessary for providing structural support to the cell and help in the process of cell growth and differentiation [92].

Regenerative medicine is a broad field where the body uses its own systems, occasionally with help foreign biological material to reconstruct cells and restructure tissues and organs. The terms "tissue engineering" and "regenerative medicine" can be used interchangeably, as the field focuses on cures instead of treatments for complex, often chronic diseases [34].

Although these areas currently play a relatively small role inpatient's treatment due to lack of reproducibility and high cost but have a greater perspective in the field of drug development to screen different medications. Currently, these are used in the regeneration of cardiac tissues, cartilage, and bone [93]. Hydrogels represent a large class of materials that can function as tissue engineering to fabricate biocompatible and biodegradable cell scaffolds [94,95]. Properties of hydrogels such as structural similarities to natural extracellular matrix, delicacy and flexibility akin to soft tissue and ability to inject easily inside the body to form irregular non flowing gels are made it useful as a scaffold material in tissue engineering. The ability of the hydrogel to show electrical conductivity also plays an excellent role in tissue engineering [96]. Lyophilization, photolithography, microfluidic, micro molding, emulsification, solvent casting-leaching, gas foaming-leaching, and 3D printing are some approaches for the production of hydrogel scaffold [97].

\subsection{Other Applications}

\subsubsection{Hydrogel Machines}

The unique properties of hydrogels, make them suitable candidate for fabricating different hydrogel machines for biomedical applications such as sensors, actuators, optics, coatings, electronics, etc. $[98,99]$. The basic requirement for this is the robustness of the hydrogels in terms of mechanical performance and functionality to ensure the stable operation of hydrogel machines. Recent innovations in the design of tough hydrogels [100,101], tough adhesion of hydrogels to other engineering materials, and advanced fabrication methods for hydrogels [102] have made hydrogels a promising material candidate for the next-generation machines [99].

\subsubsection{Biosensor}

A sensor can be defined as a machine or part of it that detects and responds to signals in the environments [103]. Conventional sensors, (electronic sensors and electrochemical sensors) convert environmental inputs to electrical outputs based on semiconductors and/or metallic electrodes; whereas, hydrogel sensors are based on exclusive characteristics of hydrogels, such as high water content, stimuli-responsiveness, high compliance, and high permeability to a wide range of molecules. They can be classified into two types: (a) stimuli-responsive hydrogels (that can exhibit according to environmental inputs) [104,105]; and (b) passive hydrogels (as matrices to host responsive substances such as free ions, nanoparticles, biomolecules, and living cells, etc. that respond to environmental inputs). Hydrogel sensors are becoming practical tools for diverse applications including point-of-care detection, medical diagnostics, and environmental monitoring, etc. [105]. 


\subsubsection{Actuator}

An actuator can be defined as a machine or a part of it that converts other forms of energy into mechanical energy to produce forces and motions. Conventional actuators adapted for mechanical systems usually contain metals and ceramics, and their actuation usually depends on relatively small deformations of the rigid materials [106]. Whereas hydrogel actuators provide mechanical motions commonly driven by relatively large deformations of the hydrogels [107]. Hydrogel actuators can be divided into three types such as (a) stimuli-responsive hydrogels driven by osmotic pressure change; (b) hydrogels matrices incorporating active elements (such as magnetic particles or free ions) in response to varying external fields (such as magnetic or electric fields); and (c) hydrogel structures with chambers.

\subsubsection{Coatings}

In the human body, many tissues and organs are covered with hydrogel coatings, resulting in extremely slippery selectively permeable surfaces. For example, articular cartilage on bones provides a lubricated surface for smooth joint movement [108]. Similarly, when rigid machines such as orthopedic implants, neural probes, cardiac sleeves, glucose sensors, needles, catheters, ultrasound transducers, and electrodes for electroencephalogram, electromyogram, electrocardiogram, and transcutaneous electrical nerve stimulation come into direct contact with the human body, hydrogel coatings can potentially provide a biocompatible interface with minimal mechanical mismatch and foreign body responses. In order to coat hydrogels on engineering materials, including metals, ceramics, glass, and elastomers, adhesion needs to form between the hydrogels and engineering materials. According to different mechanisms of hydrogel adhesion, we classify hydrogel coatings into four types: (a) physical attached [109] (b) covalent anchored (c) interracially interpenetrated, and (d) mechanically interlocked [110] hydrogel coatings.

\subsubsection{Optics}

Light and optical techniques have found particular importance in diagnosis, imaging, surgery, therapy, and many other biological types of research. Hydrogels is an ideal material for optic devices due to the above-discussed uniqueness, especially for those in close contact with biological organisms. There are two factors such as high transparency (low light absorption and scattering) and high refractive index (low bending loss) on which the effectiveness of hydrogel optics depends. According to their applications, there are four representative types of hydrogel optics developed so far, including (a) ophthalmic lenses [111], (b) smart windows and displays, (c) optical fibers [112], and (d) bioassay matrices [113].

Contact lenses are delicate ophthalmic tools that get direct contact with the eyes and are used to correct the vision, for cosmetic use imparting aesthetic effects and to deliver the active constituents for ophthalmic conditions [114]. Biocompatibility and permeability are two key properties to be considered during design besides comfort, permeable to ions for maintaining movement, continuous tear film for clear vision, non-irritable and resistance to tear film accumulation. Cornea needs oxygen for its proper functioning and therefore oxygen permeability is essential. Oxygen permeability is a very important property [115]. Principally there are two types of contact lenses, as rigid and soft contact lens.

Rigid contact lenses are typically made up of polymethyl methacrylate polymers which gives it properties such as wettability, elasticity and durability but lack of oxygen permeability. However a soft or hydrogel (poly(2-hydroxyethyl methacrylate) crosslinked with ethylene glycol dimethacrylate or silicone [116] having properties such as the ability to permeate water and oxygen with relatively high water content and good thermal and chemical stability [117]. They have the potential to assist in the treatment of various eye diseases, which is the reason why hydrogels are highly exploited as an important raw material for preparing contact lenses [118]. 


\subsubsection{Hydrogel Electronics}

Due to their similarities to biological tissues and versatility in electrical, mechanical, and bifunctional engineering, hydrogels have recently attracted growing attention in bioelectronics to potentially provide a seamless interface between biology and electronics. Hydrogels are generally considered electrical insulators due to the absence of mobile charges or charge carriers. The electrical conductivity of hydrogels in the physiologically relevant conditions is similar to that of tissue media, and much inferior to common electronic conductors such as metals, limiting their applications in electronics [119]. To overcome such limitation and enable the possibility of hydrogel electronics for improved tissue-electrode interfaces, a few strategies have been developed to enhance the electrical conductivity of hydrogels, including (a) the addition of ionic salts in the hydrogels to achieve ionically conductive hydrogels (b) incorporation of electrically conductive micro-and nano-materials within hydrogel matrices to endow electronic conductivity [120,121], and (c) introduction of conducting polymers into hydrogels to enhance electronic conductivity [122,123].

The Table 5 depicts various commercially available hydrogel products with their respective indications which give an idea about the applicability of hydrogel in various field and pave the way for future research.

Table 5. Commercially available hydrogel product.

\begin{tabular}{|c|c|c|c|c|c|c|}
\hline S.No. & Product & $\begin{array}{c}\text { Product } \\
\text { Manufactured } \\
\text { by/Marketed by }\end{array}$ & Type of Hydrogel & Active Component & Indications & Reference \\
\hline 1 & AquaDerm ${ }^{\mathrm{TM}}$ & \multirow{4}{*}{ DermaRite } & Hydrogel sheet & $\begin{array}{l}\text { 2-Acrylamido-2 methyl-1 } \\
\text { propane sulfonic acid } \\
\text { sodium, Propylene Glycol, } \\
\text { Poly (ethylene glycol) } \\
\text { dimethacrylate, 2-Hydroxy-2- } \\
\text { methylpropiophenone with } \\
\text { 38-55\% water }\end{array}$ & $\begin{array}{l}\text { Minor burns, pressure ulcers } \\
\text { and radiation tissue damage }\end{array}$ & \multirow{4}{*}{ [124] } \\
\hline 2 & DermaSyn $^{\mathrm{TM}}$ & & Amorphous hydrogel & & $\begin{array}{l}\text { Acute/chronic partial and } \\
\text { full thickness wounds/ulcers } \\
\text { having minimal exudate }\end{array}$ & \\
\hline 3 & DermaGauze $^{\mathrm{TM}}$ & & $\begin{array}{l}\text { Hydrogel impregnated } \\
\text { gauze dressing }\end{array}$ & Acrylate polymer & $\begin{array}{l}\text { Acute/chronic partial and } \\
\text { full thickness wounds having } \\
\text { minimal exudate and } \\
\text { wounds with tunneling or } \\
\text { sinus tracts }\end{array}$ & \\
\hline 4 & DermaSyn/Ag ${ }^{\mathrm{TM}}$ & & $\begin{array}{l}\text { Water-based } \\
\text { antibacterial silver } \\
\text { Wound gel }\end{array}$ & Silver & $\begin{array}{l}\text { Venous ulcers, tissue trauma, } \\
\text { pressure ulcers, diabetic } \\
\text { ulcers, surgical incisions } \\
\text { Thermal burns, etc. }\end{array}$ & \\
\hline 5 & Intrasite $^{\circledR}$ GEL & Smith and Nephew & Hydrogel & $\begin{array}{l}\text { Carboxymethyl cellulose and } \\
\text { propylene glycol }\end{array}$ & $\begin{array}{l}\text { Ease gentle, effective } \\
\text { autolytic debridement to } \\
\text { prepare the wound bed in all } \\
\text { types of wounds }\end{array}$ & [125] \\
\hline 6 & Suprasorb $^{\circledR} \mathrm{G}$ & $\begin{array}{l}\text { Lohmann and } \\
\text { Rauscher Global }\end{array}$ & Hydrogel film & $\begin{array}{c}\text { Water }(70 \%) \text {, acrylic } \\
\text { polymers based on a taurate } \\
\text { derivative, polyethylene, } \\
\text { phenoxyethanol, transparent } \\
\text { polyethylene carrier film }\end{array}$ & $\begin{array}{l}\text { Used for the management of } \\
\text { the first and second degree } \\
\text { burns, dry fractures, ulcer of } \\
\text { the lower leg, pressure } \\
\text { ulcer, etc. }\end{array}$ & [126] \\
\hline 7 & Neoheal ${ }^{\circledR}$ & Kikgel & Hydrogel sheet & $\begin{array}{c}\text { Water }(90 \%), \\
\text { polyvinylopyrrolidone, } \\
\text { polyethylene glycol and agar, } \\
\text { crosslinked by a beam } \\
\text { of electrons. }\end{array}$ & $\begin{array}{l}\text { Burns, ulcerations, bedsores } \\
\text { and all types of skin damages } \\
\text { where humid medium } \\
\text { is favourable }\end{array}$ & [127] \\
\hline 8 & $\begin{array}{c}\text { Woun'Dres }^{\circledR} \text { Collagen } \\
\text { Hydrogel }\end{array}$ & \multirow[b]{2}{*}{ Coloplast } & Collagen Hydrogel & $\begin{array}{l}\text { Polymers such as carbomer } \\
\text { and collagen }\end{array}$ & Dry wounds and eschar & \multirow[b]{2}{*}{ [128] } \\
\hline 9 & Purilon $^{\circledR}$ & & & $\begin{array}{l}\text { Water, calcium alginate } \\
\text { and sodium } \\
\text { carboxymethyl cellulose }\end{array}$ & $\begin{array}{l}\text { First and second degree } \\
\text { burns, leg ulcers, pressure } \\
\text { ulcers, non-infected diabetic } \\
\text { foot ulcers }\end{array}$ & \\
\hline 10 & Simpurity ${ }^{\circledR}$ & \multirow{2}{*}{ Safe n'Simple } & $\begin{array}{c}\text { Absorbent } \\
\text { hydrogel sheets }\end{array}$ & $\begin{array}{l}\text { water, polyethylene oxide, } \\
\text { polyvinyl alcohol, } \\
\text { acrylate, polyurethane }\end{array}$ & $\begin{array}{l}\text { Wounds with minimal to no } \\
\text { exudate, skin burns and } \\
\text { dry scabs }\end{array}$ & \multirow{2}{*}{ [129] } \\
\hline 11 & SimpurityHydroGel ${ }^{\circledR}$ & & $\begin{array}{l}\text { Impregnated Gauze } \\
\text { Wound Dressings }\end{array}$ & & $\begin{array}{l}\text { First and second degree } \\
\text { burns, pressure sores and } \\
\text { leg ulcers }\end{array}$ & \\
\hline
\end{tabular}


Table 5. Cont

\begin{tabular}{|c|c|c|c|c|c|c|}
\hline S.No. & Product & $\begin{array}{c}\text { Product } \\
\text { Manufactured } \\
\text { by/Marketed by }\end{array}$ & Type of Hydrogel & Active Component & Indications & Reference \\
\hline 12 & ProfiDerm ${ }^{\circledR}$ & Dr. Derm Professional & Hydrocollagen face gel & $\begin{array}{l}\text { Sea collagen and } \\
\text { hyaluronic acid }\end{array}$ & $\begin{array}{l}\text { Nourishes, hydrates, soothes } \\
\text { skin, helps to regenerate the } \\
\text { skin of the face, } \uparrow \text { the } \\
\text { elasticity and tones } \\
\text { the tissues }\end{array}$ & [130] \\
\hline 13 & $\begin{array}{l}\text { Advanced génifique } \\
\text { light pearl hydrogel } \\
\text { melting } 360 \text { eye mask }\end{array}$ & \multirow{2}{*}{ Lancome Paris } & Hydrogel eye mask & & $\begin{array}{c}\downarrow \text { the appearance of undereye } \\
\text { bags, puffy eyes, undereye } \\
\text { circles and rejuvenate the } \\
\text { eye area }\end{array}$ & [131] \\
\hline 14 & $\begin{array}{l}\text { Advanced génifique } \\
\text { hydrogel melting } \\
\text { sheet mask }\end{array}$ & & Hydrogel sheet mask & $\begin{array}{l}\text { Water, glycerine, } \\
\text { polyacrylate-13, } \\
\text { bifidus extract }\end{array}$ & $\begin{array}{l}\text { Moisturized face skin, and } \\
\text { make it radiant, smoother, } \\
\text { shiny and healthy }\end{array}$ & [132] \\
\hline 15 & $\begin{array}{l}\text { Water bomb } \\
\text { hydrogel mask }\end{array}$ & Moria & Hydrogel mask & $\begin{array}{l}\text { Sodium polyacrylate, } \\
\text { glycerine, cellulose } \\
\text { gum, water }\end{array}$ & $\begin{array}{c}\text { Restore hydration at a deeper } \\
\text { level, soothesand rejuvenate } \\
\text { the skin }\end{array}$ & [133] \\
\hline 16 & EautraSil $^{\mathrm{TM}}$ & \multirow[t]{2}{*}{ Miacare $^{\mathrm{TM}}$} & $\begin{array}{l}\text { Silicone Hydrogel } \\
\text { Contact Lens }\end{array}$ & $\begin{array}{l}\text { Hyaluronic Acid and } \\
\text { Sodium Alginate }\end{array}$ & $\begin{array}{l}\text { Effectively prevent } \\
\text { hypoxia-related } \\
\text { complications (corneal } \\
\text { neovascularization, redness, } \\
\text { and corneal } \\
\text { epithelium-aging) }\end{array}$ & [134] \\
\hline 17 & Confidence & & $\begin{array}{l}\text { Silicone Hydrogel Contact } \\
\text { Lens with Dot Matrix } \\
\text { Colour Printing } \\
\text { Technology }\end{array}$ & $\begin{array}{l}\text { Hyaluronic Acid and } \\
\text { Sodium Alginate }\end{array}$ & Long lasting comfort & [135] \\
\hline 18 & $\begin{array}{l}\text { Charcoal Hydrogel } \\
\text { under eye mask }\end{array}$ & ELF cosmetics & Hydrogel mask & $\begin{array}{c}\text { Charcoal Powder, Green } \\
\text { Tea Extract, } \\
\text { Lavender Extract }\end{array}$ & $\begin{array}{l}\text { Under eye skin protection } \\
\text { and rejuvenation }\end{array}$ & [136] \\
\hline 19 & SEVEN RX ${ }^{\circledR}$ & Mark'ennovy & Hydrogel lens & $\begin{array}{l}\text { Bioinspired silicone } \\
\text { hydrogel lens }\end{array}$ & Short sight and long sight & $\begin{array}{l}{[137,} \\
138]\end{array}$ \\
\hline 20 & Gentle 59 & Mark'ennovy & Bio-inspired hydrogel lens & & Short sight and long sight & [137] \\
\hline 21 & MaxvueHiToric ${ }^{\circledR}$ & Maxvue vision & Silicone hydrogel & Hyaluronic Acid & Astigmatism & {$[137]$} \\
\hline 22 & ACTIVHEAL®HYDROGEL & $\begin{array}{l}\text { Advanced medical } \\
\text { solution Ltd. }\end{array}$ & Amorphous gel & $\begin{array}{l}\text { A primary wound dressing } \\
\text { contains } 85 \% \text { water }\end{array}$ & $\begin{array}{l}\text { Dry and sloughy wounds } \\
\text { with zero to low exudate } \\
\text { such as pressure ulcers, leg } \\
\text { ulcers, cavity wounds, graft } \\
\text { at donor sites, post op } \\
\text { surgical wounds, lacerations } \\
\text { and abrasions }\end{array}$ & [139] \\
\hline 23 & $\begin{array}{c}\mathrm{Nu}-\mathrm{Gel}^{\circledR}{ }^{\circledR} \text { Hydrogel with } \\
\text { Alginate }\end{array}$ & $\begin{array}{l}\text { Systagenix wound } \\
\text { management }\end{array}$ & Hydrogel with alginate & Alginate & $\begin{array}{l}\text { Helps in management of } \\
\text { chronic wounds through all } \\
\text { stages of healing. Manage } \\
\text { dry, encrusted and necrotic, } \\
\text { sloughy, granulating } \\
\text { andepithelialising wounds. }\end{array}$ & [140] \\
\hline 24 & SUPPRELIN $^{\circledR}$ LA & $\begin{array}{l}\text { Endo Pharmaceuticals, } \\
\text { USA }\end{array}$ & Implant & Histrelin acetate & $\begin{array}{l}\text { Treatment of children having } \\
\text { central precocious puberty }\end{array}$ & [141] \\
\hline 25 & Cervidil $^{\circledR}$ & $\begin{array}{c}\text { Ferring } \\
\text { Pharmaceuticals, Inc. }\end{array}$ & $\begin{array}{l}\text { Cervidil (dinoprostone) } \\
\text { Vaginal Insert }\end{array}$ & $\begin{array}{l}\text { crosslinked polyethylene } \\
\text { oxide/urethane polymer, } \\
\text { dinoprostone }\end{array}$ & $\begin{array}{l}\text { Initiation and/or } \\
\text { continuation of cervical } \\
\text { maturement in } \\
\text { pregnant women }\end{array}$ & [142] \\
\hline 26 & SQZgel ${ }^{\mathrm{TM}}$ & MacroMed & $\begin{array}{l}\text { Controlled-release } \\
\text { oral tablets }\end{array}$ & $\begin{array}{c}\text { chitosan and } \\
\text { polyethylene glycol }\end{array}$ & Hypertension & [143] \\
\hline 27 & Mebiol ${ }^{\circledR}$ Gel & Cosmo Bio co ltd & Thermoreversible hydrogel & $\begin{array}{c}\text { poly }(\mathrm{N}- \\
\text { isopropylacrylamide }) \text { and } \\
\text { poly(ethylene glycol })\end{array}$ & $\begin{array}{l}\text { High transparency for cell } \\
\text { observation, stem cell culture, } \\
\text { cell implantation, } \\
\text { organ/tissue regeneration, } \\
\text { drug delivery, and non-cell } \\
\text { culture applications }\end{array}$ & [144] \\
\hline 28 & Gelrin $\mathrm{C}^{\mathrm{TM}}$ & $\begin{array}{c}\text { Regentis } \\
\text { Biomaterial Ltd. }\end{array}$ & Photo crosslinked hydrogel & $\begin{array}{l}\text { polyethylene glycol and } \\
\text { human fibrinogen protein }\end{array}$ & $\begin{array}{l}\text { projected for the reparation } \\
\text { of focal defects in cartilage } \\
\text { and/or osteochondral defects }\end{array}$ & [145] \\
\hline 29 & Mebiol $^{\circledR}$ Gel & Cosmo Bio & $\begin{array}{c}\text { Thermoreversible } \\
\text { Hydrogel }\end{array}$ & $\begin{array}{c}\text { Poly (N- } \\
\text { isopropylacrylamide) and } \\
\text { POLY glycol ethylene }\end{array}$ & $\begin{array}{l}\text { Cell implantation, organ and } \\
\text { tissue regeneration, stem cell } \\
\text { culture, drug delivery, and } \\
\text { non-cell culture applications }\end{array}$ & [146] \\
\hline 30 & HyStem ${ }^{\circledR}$ Hydrogel & ESI BIO & $\begin{array}{l}\text { Hyaluronic acid UV } \\
\text { light-controlled system }\end{array}$ & hyaluronic acid & $\begin{array}{c}\text { 3D cell culture for tissue } \\
\text { engineering purposes and } 3 \mathrm{D} \\
\text { printing applications }\end{array}$ & [147] \\
\hline
\end{tabular}


Table 5. Cont.

\begin{tabular}{|c|c|c|c|c|c|c|}
\hline S.No. & Product & $\begin{array}{c}\text { Product } \\
\text { Manufactured } \\
\text { by/Marketed by }\end{array}$ & Type of Hydrogel & Active Component & Indications & Reference \\
\hline 31 & $\begin{array}{c}\text { Corning }^{\circledR} \\
\text { PuraMatrix }^{\mathrm{TM}}\end{array}$ & $\begin{array}{l}\text { Corning } \\
\text { Incorporated } \\
\text { Life sciences }\end{array}$ & Peptide hydrogel & - & $\begin{array}{l}\text { 3D cell culture used for stem } \\
\text { cell proliferation, tumor cell } \\
\text { migration and invasion, and } \\
\text { in vivo analysis of } \\
\text { tissue regeneration }\end{array}$ & [148] \\
\hline 32 & Biogelx ${ }^{\mathrm{TM}}$ & Bioglex Ltd. & $\begin{array}{c}\text { Simple, short } \\
\text { self-assembling peptides }\end{array}$ & - & $\begin{array}{c}\text { Create an optimal } \\
\text { environment for the culture } \\
\text { of a variety of cell types, } \\
\text { deliver synthetic yet } \\
\text { biologically-relevant } \\
\text { alternatives to } \\
\text { animal-derived 3D matrices } \\
\text { for example matrigel } \\
\text { and collagen }\end{array}$ & [149] \\
\hline 33 & SpaceOAR ${ }^{\circledR}$ & Boston scientific & $\begin{array}{c}\text { Absorbable Injectable } \\
\text { hydrogel }\end{array}$ & - & $\begin{array}{l}\text { Imaging of cancerous cells } \\
\text { and protecting healthy cells } \\
\text { from radiation } \\
\text { induced damage }\end{array}$ & [150] \\
\hline 34 & Bulkamid $^{\circledR}$ & $\begin{array}{c}\text { Contura } \\
\text { International }\end{array}$ & $\begin{array}{l}\text { Soft injectable, } \\
\text { transparent, } \\
\text { hydrophilic gel }\end{array}$ & $\begin{array}{l}\text { Synthetic polyacrylamide } \\
\text { and water }\end{array}$ & Stress urinary incontinence & [151] \\
\hline 35 & Symphony ${ }^{\circledR}$ & Cypre's & $\begin{array}{l}\text { Stimuli-responsive } \\
\text { hydrogels as sensors }\end{array}$ & $\begin{array}{l}\text { 3D photolithographic } \\
\text { instrument }\end{array}$ & $\begin{array}{l}\text { Animal cell culture, 3D } \\
\text { imaging, iPSCs, ESc cell } \\
\text { lines, etc. }\end{array}$ & [152] \\
\hline 36 & Valleylab $^{\mathrm{TM}}$ & Medtronic & $\begin{array}{c}\text { Covalent } \\
\text { anchored coatings }\end{array}$ & $\begin{array}{c}\text { Chitosan-hyaluronic } \\
\text { acid-based hydrogel catheter }\end{array}$ & Postoperative adhesion & [153] \\
\hline 37 & Bolt Bis-Tris Plus Gels & Thermo Fisher & Bioassay matrices(gel) & Polyacrylamide gels & $\begin{array}{l}\text { Western blot transfer } \\
\text { and analysis }\end{array}$ & [154] \\
\hline 38 & Tadpole ${ }^{\mathrm{TM}}$ & Nervena ${ }^{\circledR}$ & Hydrogel electrode & $\begin{array}{c}\text { Ionically } \\
\text { conductive hydrogels }\end{array}$ & $\begin{array}{l}\text { Use in Parotidectomy and } \\
\text { otologic Surgery }\end{array}$ & \\
\hline
\end{tabular}

\section{Regulatory Aspects of Hydrogel and Its Components}

The diversified raw materials employed to develop hydrogel scaffolds make their regulatory arrangement and approval challenging. Unlike drugs which are broadly classified, hydrogels are classified under the "devices" category according to Section 201(g) of the FD\&C Act. Furthermore, other than a few exceptions, most hydrogel-based products are required to undergo additional FDA review of a $510(\mathrm{k})$ pre-market notification submission for obtaining legal marketing rights in the United States, which takes many years to get regulatory approval. However, according to the new European regulation, hydrogels are considered as medical device class III, and it should be taken into consideration throughout the entire lifecycle of the hydrogel, starting from the material and machine qualification to scale-up. Table 6 enlists some regulatory information of hydrogel ingredients used for the manufacturing of hydrogels.

The commission regulation (EU) N0 722/2012 of 8 August 2012, concerning particular requirements as regards the requirements laid down in Council Directives 90/385/EEC and 93/42/EEC. These were concerning active implantable medical devices and medical devices manufactured utilizing tissues of animal origin, has adopted a regulation based on: The original requirements, the maintenance of a high level of safety and health protection against the risk of transmitting animal spongiform encephalopathies. The regulation also considers that class III's active implantable medical devices and medical devices are subject to the conformity assessment procedures before being placed on the market or put into service, demanding the adoption of more detailed specifications relating to the risk analysis and management. The regulation establishes particular requirements concerning the placing on the market and/or putting into service of medical devices, including active implantable medical devices, manufactured utilizing animal tissue and their derivatives, originating from bovine, ovine and caprine species, deer, elk, mink and cats. In the case of collagen, gelatin and tallow used for the manufacturing of medical devices they shall meet at least the requirements as fit for human consumption. The regulation also establishes that 
the manufacturer of medical devices or his authorized representative shall carry out the risk analysis and risk management scheme before applying a conformity assessment. The member states shall verify that bodies have up-to-date knowledge of the medical devices to assess the conformity of those devices, and shall take all necessary steps to ensure that medical devices are placed on the market and/or put into service only if they comply with the current provisions and the particular requirements laid down in this regulation. Conformity assessment procedures for medical devices shall include the evaluation of compliance of the devices with the essential requirements into the current directives and the particular requirements laid down in this regulation. The manufacturer shall collect, evaluate and submit to the notified body information concerning changes regarding the animal tissue or derivatives used for the device or regarding the risk of the device.

Two new European Health Products Regulations came into force on 26 May 2017. The first one, the Regulation (EU) 2017/745 of medical devices, which modifies Directive 2001/83/EC and subsequent derived regulations, repealing Council Directives 90/385/EEC and 93/42/EEC, had been applied from 26 May 2020. The second one, Regulation (EU) 2017/746 of in vitro medical devices, which repeals both Directive 98/78/EC and the commission 2010/227/EU decision, will apply from 26 May 2022. These new regulations represent an imperative change in the medical devices field and will necessitate stringent obligations to all market operators, which results in an increase in transparency and traceability guarantees of the product further leading to safety and reliability $[155,156]$.

As hydrogels are considered a medical device class III by the new European regulation, this regulation must be considered not only in the scale-up process but also in the initial phases of the material's and the machine's invention. The regulation also considers that the active implantable medical devices and medical devices of class III are subject to the conformity assessment procedures before being placed on the market or put into service, demanding the adoption of more detailed specifications relating to the risk analysis and management. It is also considered for the elaboration of the regulation, the convenience of laying down additional provisions on the use of animal by-products not intended for human consumption, the adoption of several opinions on specified risk materials and on minimizing the risk of transmitting animal spongiform encephalopathy agents. The regulation considers that it is appropriate for the member states to verify that the notified bodies, designated to assess the conformity of those medical devices, have all the necessary expertise and up-to-date knowledge to perform this task. The period for scrutiny granted to the competent authorities of the member states concerning the notified bodies. The summary evaluation report should be shorter for medical devices manufactured using starting certified materials than in cases where uncertified materials are used. The regulation also bases its decisions on the convenience of the provision of an adequate transitional period allowing for active implantable medical devices already covered by an EC design-examination certificate or by an EC type-examination certificate to continue to be placed on the market and put into service, and that the measures provided for in this regulation are in accordance with the opinion of the Committee on Medical Device [157]. 
Table 6. Regulatory information about some hydrogel ingredients [158].

\begin{tabular}{|c|c|c|c|c|c|c|c|}
\hline Common Name & USP-NF Name & $\begin{array}{c}\text { Preferred } \\
\text { Substance Name } \\
\text { (USFDA) }\end{array}$ & EP Name & CAS No. & $\begin{array}{c}\text { Maximum Potency } \\
\text { per Unit Topical } \\
\text { Dose(as per USFDA) }\end{array}$ & $\begin{array}{c}\text { Relevant } \\
\text { Physico-Chemical } \\
\text { Properties }\end{array}$ & $\begin{array}{l}\text { GRAS } \\
\text { Listed }\end{array}$ \\
\hline Alginate & $\begin{array}{l}\text { Alginic acid, } \\
\text { sodium alginate }\end{array}$ & Sodium alginate & Alginate, sodium & $9005-38-3$ & $0.25 \% w / w$ & $\begin{array}{l}\text { Dissolves in water and } \\
\text { forms a viscous solution }\end{array}$ & $\checkmark$ \\
\hline Collagen & Gelatin & Type II Collagen & Collagen & $9007-34-5$ & $8 \% w / w$ & & $\checkmark$ \\
\hline Gelatin & Gelatin & Gelatin & Gelatin & $9000-70-8$ & $350 \mathrm{mg}$ & & $\checkmark$ \\
\hline PEG 200 & $\begin{array}{l}\text { Polyethylene } \\
\text { glycol } 200\end{array}$ & $\begin{array}{l}\text { Polyethylene } \\
\text { glycol } 200\end{array}$ & $\begin{array}{l}\text { Polyethylene } \\
\text { glycol } 200\end{array}$ & 112,607 & $39 \% w / w$ & $\begin{array}{c}\text { Viscosity } 3.9-4.8 \mathrm{mPas} \\
\text { at } 98^{\circ} \mathrm{C}\end{array}$ & $\checkmark$ \\
\hline PEG 1000 & $\begin{array}{l}\text { Polyethylene } \\
\text { glycol } 1000\end{array}$ & $\begin{array}{l}\text { Polyethylene } \\
\text { glycol } 1000\end{array}$ & $\begin{array}{l}\text { Polyethylene } \\
\text { glycol } 1000\end{array}$ & $25,322,683$ & $0.5 \% w / w$ & $\begin{array}{c}\text { Viscosity } 16-19 \mathrm{mPas} \text { at } \\
98^{\circ} \mathrm{C}\end{array}$ & \\
\hline PEG 1600 & $\begin{array}{l}\text { Polyethylene } \\
\text { glycol } 1600\end{array}$ & $\begin{array}{l}\text { Polyethylene } \\
\text { glycol } 1600\end{array}$ & $\begin{array}{l}\text { Polyethylene } \\
\text { glycol } 1600\end{array}$ & $25,322,683$ & $29.7 \% w / w$ & $\begin{array}{c}\text { Viscosity } 28-36 \mathrm{mPas} \text { at } \\
98^{\circ} \mathrm{C}\end{array}$ & $\checkmark$ \\
\hline PEG 300 & $\begin{array}{l}\text { Polyethylene } \\
\text { glycol } 300\end{array}$ & $\begin{array}{l}\text { Polyethylene } \\
\text { glycol } 300\end{array}$ & $\begin{array}{l}\text { Polyethylene } \\
\text { glycol } 300\end{array}$ & $25,322,683$ & $57 \% w / w$ & $\begin{array}{c}\text { Viscosity } 5.4-6.4 \mathrm{mPas} \\
\text { at } 98^{\circ} \mathrm{C}\end{array}$ & $\checkmark$ \\
\hline PEG 400 & $\begin{array}{l}\text { Polyethylene } \\
\text { glycol } 400\end{array}$ & $\begin{array}{l}\text { Polyethylene } \\
\text { glycol } 400\end{array}$ & $\begin{array}{l}\text { Polyethylene } \\
\text { glycol } 400\end{array}$ & $25,322,683$ & $99 \% w / v$ & $\begin{array}{c}\text { Viscosity } 6.8-8 \mathrm{mPas} \text { at } \\
98^{\circ} \mathrm{C}\end{array}$ & $\checkmark$ \\
\hline Polyacrylic acid & Poly(acrylic acid) & Polyacrylic acid & Polyacrylate & 9003-01-4 & $196 \mathrm{mg}$ & $\begin{array}{c}\text { Viscosity } 50-200 \mathrm{mPas} \\
\text { at } 20^{\circ} \mathrm{C}\end{array}$ & $\checkmark$ \\
\hline Polyvinyl alcohol & $\begin{array}{l}\text { Polyvinyl } \\
\text { alcohol }\end{array}$ & $\begin{array}{l}\text { Polyvinyl } \\
\text { alcohol }\end{array}$ & $\begin{array}{l}\text { Polyvinyl } \\
\text { alcohol }\end{array}$ & $9002-89-5$ & $140 \mathrm{mg}$ & & $\checkmark$ \\
\hline Polyacrylamide & Polyacrylamide & Polyacrylamide & Polyacrylamide & $9003-05-8$ & $5 \% w / w$ & & $\checkmark$ \\
\hline
\end{tabular}

\section{Conclusions}

Hydrogels are a highly porous system and the polymers building them could be cross-connected to change degrees by altering their densities. Further, this porosity and the crosslinking ratio of hydrogel play a vital role in the release of medicaments. Applications of hydrogels are not simply restricted to focus medication conveyance they additionally discover applications in cleanliness items, wound dressings, contact focal points, tissue and machine designing. Further, it uses "smart" polymers capable of responding to various ecological signals permits administration of polymeric solution and undergo gelation under physiological conditions leading to in-situ hydrogels formation. However, preformed hydrogels are conventionally used for various applications as wound scaffolds; having the ability to release antimicrobial or anti-inflammatory drugs and growth factors from their structure by aiding the regeneration of the tissue. Additionally, hydrogels can be functionalized with a radiopaque that provides X-ray opacity and allows them to be used as biomedical implants for in vivo visualization and evaluation of the ability to prevent postoperative adhesions. Hydrogels are very versatile allowing varieties of the route for administrating drugs. In summary, hydrogels represent one of the most versatile technological platforms for pharmaceutical innovation.

Ongoing improvements of hydrogels in the field of focused medication conveyance have been colossal. They are altered by focusing on ligands and different polymer types that present intriguing properties for drug transportation. Ophthalmic medication conveyance is a territory seeing the huge effect in treatment from hydrogels. From agreeable contact focal points to biodegradable medication conveyance the applications in eye care have been colossal. They are $90 \%$ water, give consistent drug discharge over days or months capable of conveying little particles to huge proteins, are completely invested in conveyance and stay noticeable during checking.

It is clear that there is a lot of potential in the field of hydrogels and number of setbacks which have to be overcome. Several investigators have shown significant results for improving the efficiency of hydrogel based drug delivery system. In tissue engineering fabrication technique based on in situ crosslinked hydrogel is much appreciated. Extensive studies have been conducted, and the number of patents published in this area of hydrogels has been increasing which is promising. Therefore, over the years, hydrogels became key players in the biomedical field in general and pharmaceutical research and 
development in particular, employing different invasive and minimally invasive administration routes. Future research in hydrogels will concentrate on the design of 3D structures with programmed bio functionality. There is a critical need to study major factors involved in the formation of hydrogels and to establish the different physicochemical criteria for the formation of reproducible, reversible 3D hydrogel networks with precisely defined structures and properties.

Author Contributions: Conceptualization, M.A.M. and S.M. (Syed Mahmood); original draft, S.M. (Sradhanjali Mohapatra); data curation, S.M. (Sradhanjali Mohapatra), A.R.H. and F.Z.; funding acquisition, S.M. (Syed Mahmood), M.J.A. and Z.I.; supervision, S.M. (Syed Mahmood) and Z.I.; writing—review and editing, M.J.A. and A.C.G. All authors have read and agreed to the publisher version of the manuscript.

Funding: This research received no external funding.

Institutional Review Board Statement: Not applicable.

Informed Consent Statement: Not applicable.

Acknowledgments: The authors are highly grateful towards Jamia Hamdard and DST for providing support in the form of DST PURSE. In addition, we would to thank Universiti Malaya for providing the facilities.

Conflicts of Interest: The authors declare no conflict of interest.

\section{References}

1. Chirani, N.; Gritsch, L.; Motta, F.L.; Fare, S. History and Applications of Hydrogels. J. Biomed. Sci. 2015, 4. [CrossRef]

2. Hoare, T.R.; Kohane, D.S. Hydrogels in drug delivery: Progress and challenges. Polymer 2008, 49, 1993-2007. [CrossRef]

3. Ahmed, E.M. Hydrogel: Preparation, characterization, and applications: A review. J. Adv. Res. 2015, 6, 105-121. [CrossRef] [PubMed]

4. Chen, C.-H.; Kuo, C.-Y.; Chen, S.-H.; Mao, S.-H.; Chang, C.-Y.; Shalumon, K.T.; Chen, J.-P. Thermosensitive Injectable Hydrogel for Simultaneous Intraperitoneal Delivery of Doxorubicin and Prevention of Peritoneal Adhesion. Int. J. Mol. Sci. 2018, 19, 1373. [CrossRef] [PubMed]

5. Wichterle, O.; Lím, D. Hydrophilic Gels for Biological Use. Nat. Cell Biol. 1960, 185, 117-118. [CrossRef]

6. Ullah, F.; Othman, M.B.H.; Javed, F.; Ahmad, Z.; Akil, H.M. Classification, processing and application of hydrogels: A review. Mater. Sci. Eng. C 2015, 57, 414-433. [CrossRef]

7. Zhou, L.; Fan, R.; Tong, A.; Li, X.; Gao, X.; Mei, L.; Zhang, X.; You, C.; Guo, G. Enhanced antitumor effects by docetaxel/LL37-loaded thermosensitive hydrogel nanoparticles in peritoneal carcinomatosis of colorectal cancer. Int. J. Nanomed. 2015, 10, 7291-7305. [CrossRef]

8. Fan, D.-Y.; Tian, Y.; Liu, Z.-J. Injectable Hydrogels for Localized Cancer Therapy. Front. Chem. 2019, 7. [CrossRef]

9. Hasan, A.M.A.; Abdel-Raouf, M.E.-S. Cellulose-Based Superabsorbent Hydrogels; Springer: Berlin/Heidelberg, Germany, 2019.

10. Stebe, K.J.; Lin, S.-Y. Dynamic surface tension and surfactant mass transfer kinetics: Measurement Techniques and analysis. Handbook Surf. Interfaces Mater. 2001, 55-106.

11. Nagam, S.P.; Naga Jyothi, A.; Poojitha, J.; Aruna, S.; Nadendla, R.R. A Comprehensive review on hydrogels. Int. J. Curr. Pharm. Rev. Res. 2016, 8, 19-23.

12. Caló, E.; Khutoryanskiy, V. Biomedical applications of hydrogels: A review of patents and commercial products. Eur. Polym. J. 2015, 65, 252-267. [CrossRef]

13. Russo, E.; Villa, C. Poloxamer Hydrogels for Biomedical Applications. Pharmaceutics 2019, 11, 671. [CrossRef]

14. Yu, Y.; Cheng, Y.; Tong, J.; Zhang, L.; Wei, Y.; Tian, M. Recent advances in thermo-sensitive hydrogels for drug delivery. J. Mater. Chem. B 2021, 9, 2979-2992. [CrossRef]

15. Okay, O. Hydrogel Sensors and Actuators; Springer: Berlin/Heidelberg, Germany, 2010; ISBN 978-3-540-75644-6.

16. Gerlach, G.; Arndt, K. Hydrogel sensors and actuators volume. In Springer Series on Chemical Sensors and Biosensors; Springer: Berlin/Heidelberg, Germany, 2013; ISBN 9783540756446.

17. Byju, A.G.; Kulkarni, A.; Gundiah, N. Mechanics of gelatin and elastin based hydrogels as tissue engineered constructs. In Proceedings of the 13th International Conference on Fracture, ICF 2013, Beijing, China, 16-21 June 2013.

18. Oyen, M.L. Mechanical characterisation of hydrogel materials. Int. Mater. Rev. 2013, 59, 44-59. [CrossRef]

19. Hua, J.; Ng, P.F.; Fei, B. High-strength hydrogels: Microstructure design, characterization and applications. J. Polym. Sci. Part B Polym. Phys. 2018, 56, 1325-1335. [CrossRef]

20. Salerno, A.; Borzacchiello, R.; Netti, P.A. Pore structure and swelling behavior of porous hydrogels prepared via a thermal reverse-casting technique. J. Appl. Polym. Sci. 2011, 122, 3651-3660. [CrossRef] 
21. Siboro, S.A.; Anugrah, D.S.; Ramesh, K.; Park, S.-H.; Kim, H.-R.; Lim, K.T. Tunable porosity of covalently crosslinked alginatebased hydrogels and its significance in drug release behavior. Carbohydr. Polym. 2021, 260, 117779. [CrossRef]

22. Dong, L.C.; Hoffman, A.S.; Yan, Q. Dextran permeation through poly(N-isopropylacrylamide) Hydrogels. J. Biomater. Sci. Polym. Ed. 1994, 5, 473-484. [CrossRef]

23. ASTM. F2450-10: Standard Guide for Assessing Microstructure of Polymeric Scaffolds for Use in Tissue-Engineered Medical Products. In ASTM Book of Standards; ASTM: West Conshohocken, PA, USA, 2013.

24. Fathima, N.N.; Dhathathreyan, A.; Ramasami, T. Mercury Intrusion Porosimetry, Nitrogen Adsorption, and Scanning Electron Microscopy Analysis of Pores in Skin. Biomacromolecules 2002, 3, 899-904. [CrossRef]

25. Hay, J.; Laity, P. Observations of water migration during thermoporometry studies of cellulose films. Polymers 2000, 41, 6171-6180. [CrossRef]

26. Landry, M.R. Thermoporometry by differential scanning calorimetry: Experimental considerations and applications. Thermochim. Acta 2005, 433, 27-50. [CrossRef]

27. Yamamoto, T.; Endo, A.; Inagi, Y.; Ohmori, T.; Nakaiwa, M. Evaluation of thermoporometry for characterization of mesoporous materials. J. Colloid Interface Sci. 2005, 284, 614-620. [CrossRef]

28. Maitra, J.; Shukla, V.K. Cross-linking in Hydrogels-A Review. Am. J. Polym. Sci. 2014, 4, 25-31. [CrossRef]

29. Weber, L.M.; Lopez, C.G.; Anseth, K.S. Effects of PEG hydrogel crosslinking density on protein diffusion and encapsulated islet survival and function. J. Biomed. Mater. Res. Part A 2009, 90A, 720-729. [CrossRef] [PubMed]

30. Sung, H.-W.; Huang, D.-M.; Chang, W.-H.; Huang, R.N.; Hsu, J.-C. Evaluation of gelatin hydrogel crosslinked with various crosslinking agents as bioadhesives:In vitro study. J. Biomed. Mater. Res. 1999, 46, 520-530. [CrossRef]

31. Parhi, R. Cross-Linked Hydrogel for Pharmaceutical Applications: A Review. Adv. Pharm. Bull. 2017, 7, 515-530. [CrossRef] [PubMed]

32. Gulrez, H.S.K.; Al-Assaf, S.O.G. Hydrogels: Methods of Preparation, Characterisation and Applications. In Progress in Molecular and Environmental Bioengineering_-From Analysis and Modeling to Technology Applications; IntechOpen: London, UK, 2011.

33. Bahram, M.; Mohseni, N.; Moghtader, M. An Introduction to Hydrogels and Some Recent Applications; InTech Open: Rijeka, Croatia, 2016.

34. Aswathy, S.; Narendrakumar, U.; Manjubala, I. Commercial hydrogels for biomedical applications. Heliyon 2020, 6, e03719. [CrossRef] [PubMed]

35. Verdier-Sévrain, S.; Bonté, F. Skin hydration: A review on its molecular mechanisms. J. Cosmet. Dermatol. 2007, 6, 75-82. [CrossRef]

36. Mitura, S.; Sionkowska, A.; Jaiswal, A.K. Biopolymers for hydrogels in cosmetics: Review. J. Mater. Sci. Mater. Med. 2020, 31, 1-14. [CrossRef]

37. Herndon, D.N.; Barrow, R.E.; Rutan, R.L.; Rutan, T.C.; Desai, M.H.; Abston, S. A Comparison of Conservative Versus Early Excision. Ann. Surg. 1989, 209, 547-553. [CrossRef]

38. Francesko, A.; Petkova, P.; Tzanov, T. Hydrogel Dressings for Advanced Wound Management. Curr. Med. Chem. 2018, 25, 5782-5797. [CrossRef]

39. Rimmer, S. Biomedical Hydrogels: Biochemistry, Manufacture and Medical Applications; Elsevier: Amsterdam, The Netherlands, 2011; ISBN 9781845695903.

40. Gupta, A.; Kowalczuk, M.; Heaselgrave, W.; Britland, S.T.; Martin, C.; Radecka, I. The production and application of hydrogels for wound management: A review. Eur. Polym. J. 2019, 111, 134-151. [CrossRef]

41. Tavakoli, S.; Klar, A.S. Advanced Hydrogels as Wound Dressings. Biomolecules 2020, 10, 1169. [CrossRef]

42. Tiwari, G.; Tiwari, R.; Sriwastawa, B.; Bhati, L.; Pandey, S.; Pandey, P.; Bannerjee, S.K. Drug delivery systems: An updated review. Int. J. Pharm. Investig. 2012, 2, 2-11. [CrossRef]

43. Narayanaswamy, R.; Torchilin, V.P. Hydrogels and Their Applications in Targeted Drug Delivery. Molecules 2019, $24,603$. [CrossRef]

44. Ashley, G.W.; Henise, J.; Reid, R.; Santi, D.V. Hydrogel drug delivery system with predictable and tunable drug release and degradation rates. Proc. Natl. Acad. Sci. USA 2013, 110, 2318-2323. [CrossRef]

45. Larrañeta, E.; Stewart, S.; Ervine, M.; Al-Kasasbeh, R.; Donnelly, R.F. Hydrogels for Hydrophobic Drug Delivery. Classification, Synthesis and Applications. J. Funct. Biomater. 2018, 9, 13. [CrossRef]

46. Bindu Sri, M.; Ashok, V.; Arkendu, C. As A Review on Hydrogels as Drug Delivery in the Pharmaceutical Field. Int. J. Pharm. Chem. Sci. 2012, 1, 642-741.

47. Kirschner, C.M.; Anseth, K.S. Hydrogels in healthcare: From static to dynamic material microenvironments. Acta Mater. 2013, 61, 931-944. [CrossRef]

48. Baumann, M.D.; Kang, C.E.; Stanwick, J.C.; Wang, Y.; Kim, H.; Lapitsky, Y.; Shoichet, M.S. An injectable drug delivery platform for sustained combination therapy. J. Control. Release 2009, 138, 205-213. [CrossRef]

49. Marefat Seyedlar, R.; Imani, M.; Atai, M.; Nodehi, A. Temperature-Responsive Hydrogels: Materials, Mechanisms and Biological Applications. Iran. J. Polym. Sci. Technol. Persian 2018, 31, 211-237.

50. Pereira, R.F.; Bártolo, P.J. Photopolymerizable hydrogels in regenerative medicine and drug delivery. In Hot Topics in Biomaterials; Future Science Ltd.: London, UK, 2014; pp. 6-28.

51. Raza, A.; Rasheed, T.; Nabeel, F.; Hayat, U.; Bilal, M.; Iqbal, H.M.N. Endogenous and Exogenous Stimuli-Responsive Drug Delivery Systems for Programmed Site-Specific Release. Molecules 2019, 24, 1117. [CrossRef] 
52. Kim, D.Y.; Kwon, D.Y.; Kwon, J.S.; Kim, J.H.; Min, B.H.; Kim, M.S. Stimuli-Responsive Injectable In situ-Forming Hydrogels for Regenerative Medicines. Polym. Rev. 2015, 55, 407-452. [CrossRef]

53. Nezhad-Mokhtari, P.; Akrami-Hasan-Kohal, M.; Ghorbani, M. An injectable chitosan-based hydrogel scaffold containing gold nanoparticles for tissue engineering applications. Int. J. Biol. Macromol. 2020, 154, 198-205. [CrossRef]

54. Yan, S.; Zhang, X.; Zhang, K.; Di, H.; Feng, L.; Li, G.; Fang, J.; Cui, L.; Chen, X.; Yin, J. Injectable in situ forming poly(l-glutamic acid) hydrogels for cartilage tissue engineering. J. Mater. Chem. B 2016, 4, 947-961. [CrossRef]

55. Shu, C.; Li, R.; Yin, Y.; Yin, D.; Gu, Y.; Ding, L.; Zhong, W. Synergistic dual-targeting hydrogel improves targeting and anticancer effect of Taxol in vitro and in vivo. Chem. Commun. 2014, 50, 15423-15426. [CrossRef]

56. Jin, X.; Fu, Q.; Gu, Z.; Zhang, Z.; Lv, H. Injectable corilagin/low molecular weight chitosan/PLGA-PEG-PLGA thermosensitive hydrogels for localized cancer therapy and promoting drug infiltration by modulation of tumor microenvironment. Int. J. Pharm. 2020, 589, 119772. [CrossRef]

57. Luque-Michel, E.; Imbuluzqueta, E.; Sebastián, V.; Blanco-Prieto, M.J. Clinical advances of nanocarrier-based cancer therapy and diagnostics. Expert Opin. Drug Deliv. 2017, 14, 75-92. [CrossRef]

58. Perche, F.; Biswas, S.; Torchilin, V.P. Stimuli-Sensitive Polymeric Nanomedicines for Cancer Imaging and Therapy. In Handbook of Polymers for Pharmaceutical Technologies; Wiley: Hoboken, NJ, USA, 2015; pp. 311-344.

59. Moreira, A.F.; Dias, D.R.; Costa, E.C.; Correia, I.J. Thermo- and pH-responsive nano-in-micro particles for combinatorial drug delivery to cancer cells. Eur. J. Pharm. Sci. 2017, 104, 42-51. [CrossRef]

60. Ma, J.; Li, X.; Bao, Y. Advances in cellulose-based superabsorbent hydrogels. RSC Adv. 2015, 5, 59745-59757. [CrossRef]

61. Ahsan, A.; Farooq, M.A.; Parveen, A. Thermosensitive Chitosan-Based Injectable Hydrogel as an Efficient Anticancer Drug Carrier. ACS Omega 2020, 5, 20450-20460. [CrossRef] [PubMed]

62. Fathi, M.; Alami-Milani, M.; Geranmayeh, M.H.; Barar, J.; Erfan-Niya, H.; Omidi, Y. Dual thermo-and pH-sensitive injectable hydrogels of chitosan/(poly(N-isopropylacrylamide-co-itaconic acid)) for doxorubicin delivery in breast cancer. Int. J. Biol. Macromol. 2019, 128, 957-964. [CrossRef] [PubMed]

63. Chen, X.; Wang, M.; Yang, X.; Wang, Y.; Yu, L.; Sun, J.; Ding, J. Injectable hydrogels for the sustained delivery of a HER2-targeted antibody for preventing local relapse of HER2+ breast cancer after breast-conserving surgery. Theranostics 2019, 9, 6080-6098 [CrossRef] [PubMed]

64. Qu, J.; Zhao, X.; Ma, P.X.; Guo, B. pH-responsive self-healing injectable hydrogel based on $\mathrm{N}$-carboxyethyl chitosan for hepatocellular carcinoma therapy. Acta Biomater. 2017, 58, 168-180. [CrossRef]

65. Le, T.M.D.; Jung, B.-K.; Li, Y.; Duong, H.T.T.; Nguyen, T.L.; Hong, J.W.; Yun, C.-O.; Lee, D.S. Physically crosslinked injectable hydrogels for long-term delivery of oncolytic adenoviruses for cancer treatment. Biomater. Sci. 2019, 7, 4195-4207. [CrossRef]

66. Jiang, Y.-W.; Gao, G.; Hu, P.; Liu, J.-B.; Guo, Y.; Zhang, X.; Yu, X.-W.; Wu, F.-G.; Lu, X. Palladium nanosheet-knotted injectable hydrogels formed via palladium-sulfur bonding for synergistic chemo-photothermal therapy. Nanoscale 2020, 12, 210-219. [CrossRef]

67. Lee, A.L.Z.; Ng, V.W.L.; Gao, S.; Hedrick, J.L.; Yang, Y.Y. Injectable Biodegradable Hydrogels from Vitamin D-Functionalized Polycarbonates for the Delivery of Avastin with Enhanced Therapeutic Efficiency against Metastatic Colorectal Cancer. Biomacromolecules 2015, 16, 465-475. [CrossRef]

68. Bubpamala, T.; Viravaidya-Pasuwat, K.; Pholpabu, P. Injectable Poly(ethylene glycol) Hydrogels Cross-Linked by Metal-Phenolic Complex and Albumin for Controlled Drug Release. ACS Omega 2020, 5, 19437-19445. [CrossRef]

69. Lee, A.L.Z.; Ng, V.W.L.; Gao, S.; Hedrick, J.L.; Yang, Y.Y. Injectable Hydrogels from Triblock Copolymers of Vitamin EFunctionalized Polycarbonate and Poly(ethylene glycol) for Subcutaneous Delivery of Antibodies for Cancer Therapy. Adv. Funct. Mater. 2014, 24, 1538-1550. [CrossRef]

70. Liang, Y.; Zhao, X.; Ma, P.X.; Guo, B.; Du, Y.; Han, X. pH-responsive injectable hydrogels with mucosal adhesiveness based on chitosan-grafted-dihydrocaffeic acid and oxidized pullulan for localized drug delivery. J. Colloid Interface Sci. 2019, 536, $224-234$. [CrossRef]

71. Silva, E.A.; Mooney, D. Spatiotemporal control of vascular endothelial growth factor delivery from injectable hydrogels enhances angiogenesis. J. Thromb. Haemost. 2007, 5, 590-598. [CrossRef]

72. Hu, C.; Zhang, F.; Long, L.; Kong, Q.; Luo, R.; Wang, Y. Dual-responsive injectable hydrogels encapsulating drug-loaded micelles for on-demand antimicrobial activity and accelerated wound healing. J. Control. Release 2020, 324, 204-217. [CrossRef]

73. Fletcher, N.A.; Babcock, L.R.; Murray, E.A.; Krebs, M.D. Controlled delivery of antibodies from injectable hydrogels. Mater. Sci. Eng. C 2016, 59, 801-806. [CrossRef]

74. Ren, Y.; Zhao, X.; Liang, X.; Ma, P.X.; Guo, B. Injectable hydrogel based on quaternized chitosan, gelatin and dopamine as localized drug delivery system to treat Parkinson's disease. Int. J. Biol. Macromol. 2017, 105, 1079-1087. [CrossRef]

75. Xing, L.; Sun, J.; Tan, H.; Yuan, G.; Li, J.; Jia, Y.; Xiong, D.; Chen, G.; Lai, J.; Ling, Z.; et al. Covalently polysaccharide-based alginate/chitosan hydrogel embedded alginate microspheres for BSA encapsulation and soft tissue engineering. Int. J. Biol. Macromol. 2019, 127, 340-348. [CrossRef]

76. Dromel, P.C.; Singh, D.; Christoff-Tempesta, T.; Martheswaran, M.T.; Alexander-Katz, A.; Spector, M.; Young, M. Controlling Growth Factor Diffusion by Modulating Water Content in Injectable Hydrogels. Tissue Eng. Part A 2021, 27, 714-723. [CrossRef]

77. Verbeke, C.; Gordo, S.; Schubert, D.A.; Lewin, S.A.; Desai, R.M.; Dobbins, J.; Wucherpfennig, K.W.; Mooney, D.J. Multicomponent Injectable Hydrogels for Antigen-Specific Tolerogenic Immune Modulation. Adv. Healthc. Mater. 2017, 6. [CrossRef] 
78. Qu, J.; Zhao, X.; Liang, Y.; Zhang, T.; Ma, P.X.; Guo, B. Antibacterial adhesive injectable hydrogels with rapid self-healing, extensibility and compressibility as wound dressing for joints skin wound healing. Biomaterials 2018, 183, 185-199. [CrossRef]

79. Wang, K.; Mitra, R.N.; Zheng, M.; Han, Z. Nanoceria-loaded injectable hydrogels for potential age-related macular degeneration treatment. J. Biomed. Mater. Res. Part A 2018, 106, 2795-2804. [CrossRef]

80. Ungerleider, J.; Johnson, T.; Rao, N.; Christman, K. Fabrication and characterization of injectable hydrogels derived from decellularized skeletal and cardiac muscle. Methods 2015, 84, 53-59. [CrossRef]

81. Wei, Z.; Zhao, J.; Chen, Y.M.; Zhang, P.; Zhang, Q. Self-healing polysaccharide-based hydrogels as injectable carriers for neural stem cells. Sci. Rep. 2016, 6, 37841. [CrossRef]

82. Von Lospichl, B.; Hemmati-Sadeghi, S.; Dey, P.; Dehne, T.; Haag, R.; Sittinger, M.; Ringe, J.; Gradzielski, M. Injectable hydrogels for treatment of osteoarthritis—A rheological study. Colloids Surf. B Biointerfaces 2017, 159, 477-483. [CrossRef]

83. Qu, J.; Zhao, X.; Liang, Y.; Xu, Y.; Ma, P.X.; Guo, B. Degradable conductive injectable hydrogels as novel antibacterial, anti-oxidant wound dressings for wound healing. Chem. Eng. J. 2019, 362, 548-560. [CrossRef]

84. Dong, Y.; Rodrigues, M.; Li, X.; Kwon, S.H.; Kosaric, N.; Khong, S.; Gao, Y.; Wang, W.; Gurtner, G.C. Injectable and Tunable Gelatin Hydrogels Enhance Stem Cell Retention and Improve Cutaneous Wound Healing. Adv. Funct. Mater. 2017, 27. [CrossRef]

85. Feng, G.; Zha, Z.; Huang, Y.; Li, J.; Wang, Y.; Ke, W.; Chen, H.; Liu, L.; Song, Y.; Ge, Z. Sustained and Bioresponsive Two-Stage Delivery of Therapeutic miRNA via Polyplex Micelle-Loaded Injectable Hydrogels for Inhibition of Intervertebral Disc Fibrosis. Adv. Healthc. Mater. 2018, 7, e1800623. [CrossRef]

86. Shaghiera, A.D.; Widiyanti, P.; Yusuf, H. Synthesis and Characterization of Injectable Hydrogels with Varying Collagen-ChitosanThymosin $\beta 4$ Composition for Myocardial Infarction Therapy. J. Funct. Biomater. 2018, 9, 33. [CrossRef]

87. Zhang, K.; Zhao, X.; Chen, X.; Wei, Y.; Du, W.; Wang, Y.; Liu, L.; Zhao, W.; Han, Z.; Kong, D.; et al. Enhanced Therapeutic Effects of Mesenchymal Stem Cell-Derived Exosomes with an Injectable Hydrogel for Hindlimb Ischemia Treatment. ACS Appl. Mater. Interfaces 2018, 10, 30081-30091. [CrossRef]

88. Xie, B.; Jin, L.; Luo, Z.; Yu, J.; Shi, S.; Zhang, Z.; Shen, M.; Chen, H.; Li, X.; Song, Z. An injectable thermosensitive polymeric hydrogel for sustained release of Avastin®to treat posterior segment disease. Int. J. Pharm. 2015, 490, 375-383. [CrossRef]

89. Steele, A.N.; Stapleton, L.M.; Farry, J.; Lucian, H.J.; Paulsen, M.J.; Eskandari, A.; Hironaka, C.E.; Thakore, A.D.; Wang, H.; Yu, A.C.; et al. A Biocompatible Therapeutic Catheter-Deliverable Hydrogel for In Situ Tissue Engineering. Adv. Healthc. Mater. 2019, 8. [CrossRef]

90. Lü, S.; Gao, C.; Xu, X.; Bai, X.; Duan, H.; Gao, N.; Feng, C.; Xiong, Y.; Liu, M. Injectable and Self-Healing Carbohydrate-Based Hydrogel for Cell Encapsulation. ACS Appl. Mater. Interfaces 2015, 7, 13029-13037. [CrossRef]

91. Vong, L.B.; Bui, T.Q.; Tomita, T.; Sakamoto, H.; Hiramatsu, Y.; Nagasaki, Y. Novel angiogenesis therapeutics by redox injectable hydrogel - Regulation of local nitric oxide generation for effective cardiovascular therapy. Biomaterials 2018, 167, 143-152. [CrossRef] [PubMed]

92. Cascone, S.; Lamberti, G. Hydrogel-based commercial products for biomedical applications: A review. Int. J. Pharm. 2020, 573, 118803. [CrossRef] [PubMed]

93. Ren, K.; He, C.; Xiao, C.; Li, G.; Chen, X. Injectable glycopolypeptide hydrogels as biomimetic scaffolds for cartilage tissue engineering. Biomaterials. 2015, 51, 238-249. [CrossRef]

94. Cheung, H.K.; Han, T.T.Y.; Marecak, D.M.; Watkins, J.F.; Amsden, B.G.; Flynn, L.E. Composite hydrogel scaffolds incorporating decellularized adipose tissue for soft tissue engineering with adipose-derived stem cells. Biomaterials 2014, 35, 1914-1923. [CrossRef] [PubMed]

95. Brown, C.F.C.; Yan, J.; Han, T.T.Y.; Marecak, D.M.; Amsden, B.G.; Flynn, L.E. Effect of decellularized adipose tissue particle size and cell density on adipose-derived stem cell proliferation and adipogenic differentiation in composite methacrylated chondroitin sulphate hydrogels. Biomed. Mater. 2015, 10, 045010. [CrossRef] [PubMed]

96. Yang, B.; Yao, F.; Hao, T.; Fang, W.; Ye, L.; Zhang, Y.; Wang, Y.; Li, J.; Wang, C. Development of Electrically Conductive Double-Network Hydrogels via One-Step Facile Strategy for Cardiac Tissue Engineering. Adv. Healthc. Mater. 2016, 5, 474-488. [CrossRef]

97. El-Sherbiny, I.M.; Yacoub, M.H. Hydrogel scaffolds for tissue engineering: Progress and challenges. Glob. Cardiol. Sci. Pract. 2013, 2013, 316-342. [CrossRef] [PubMed]

98. Chaterji, S.; Kwon, I.K.; Park, K. Smart polymeric gels: Redefining the limits of biomedical devices. Prog. Polym. Sci. 2007, 32, 1083-1122. [CrossRef]

99. Liu, X.; Liu, J.; Lin, S.; Zhao, X. Hydrogel machines. Mater. Today 2020, 36, 102-124. [CrossRef]

100. Calvert, P. Hydrogels for Soft Machines. Adv. Mater. 2009, 21, 743-756. [CrossRef]

101. Yuk, H.; Zhang, T.; Lin, S.; Parada, G.A.; Zhao, X. Tough bonding of hydrogels to diverse non-porous surfaces. Nat. Mater. 2016, 15, 190-196. [CrossRef]

102. Hong, S.; Sycks, D.; Chan, H.F.; Lin, S.; Lopez, G.P.; Guilak, F.; Leong, K.W.; Zhao, X. 3D Printing: 3D Printing of Highly Stretchable and Tough Hydrogels into Complex, Cellularized Structures (Adv. Mater. 27/2015). Adv. Mater. 2015, $27,4034$. [CrossRef]

103. Buenger, D.; Topuz, F.; Groll, J. Hydrogels in sensing applications. Prog. Polym. Sci. 2012, 37, 1678-1719. [CrossRef]

104. Pinelli, F.; Magagnin, L.; Rossi, F. Progress in hydrogels for sensing applications: A review. Mater. Today Chem. 2020, $17,100317$. [CrossRef] 
105. Shin, J.; Braun, P.V.; Lee, W. Fast response photonic crystal pH sensor based on templated photo-polymerized hydrogel inverse opal. Sens. Actuators B Chem. 2010, 150, 183-190. [CrossRef]

106. Huber, J.E.; Fleck, N.A.; Ashby, M.F. The selection of mechanical actuators based on performance indices. In Royal Society A: Mathematical, Physical and Engineering Sciences; The Royal Society: London, UK, 1997; Volume 453, pp. $2185-2205$.

107. Keplinger, C.; Sun, J.-Y.; Foo, C.C.; Rothemund, P.; Whitesides, G.M.; Suo, Z. Stretchable, Transparent, Ionic Conductors. Science 2013, 341, 984-987. [CrossRef]

108. Fox, A.J.S.; Bedi, A.; Rodeo, S.A. The Basic Science of Articular Cartilage: Structure, Composition, and Function. Sports Health A Multidiscip. Approach 2009, 1, 461-468. [CrossRef]

109. Yu, B.; Wang, C.; Ju, Y.M.; West, L.; Harmon, J.; Moussy, Y.; Moussy, F. Use of hydrogel coating to improve the performance of implanted glucose sensors. Biosens. Bioelectron. 2008, 23, 1278-1284. [CrossRef]

110. Kurokawa, T.; Furukawa, H.; Wang, W.; Tanaka, Y.; Gong, J.P. Formation of a strong hydrogel-porous solid interface via the double-network principle. Acta Biomater. 2010, 6, 1353-1359. [CrossRef]

111. Zhang, Q.; Fang, Z.; Cao, Y.; Du, H.; Wu, H.; Beuerman, R.; Chan-Park, M.B.; Duan, H.; Xu, R. High Refractive Index InorganicOrganic Interpenetrating Polymer Network (IPN) Hydrogel Nanocomposite toward Artificial Cornea Implants. ACS Macro Lett. 2012, 1, 876-881. [CrossRef]

112. Choi, M.; Humar, M.; Kim, S.; Yun, S.-H. Step-Index Optical Fiber Made of Biocompatible Hydrogels. Adv. Mater. 2015, 27, 4081-4086. [CrossRef]

113. Chung, K.; Wallace, J.; Kim, S.-Y.; Kalyanasundaram, S.; Andalman, A.S.; Davidson, T.J.; Mirzabekov, J.J.; Zalocusky, K.A.; Mattis, J.; Denisin, A.; et al. Structural and molecular interrogation of intact biological systems. Nat. Cell Biol. 2013, 497, 332-337. [CrossRef]

114. Farandos, N.M.; Yetisen, A.K.; Monteiro, M.J.; Lowe, C.R.; Yun, S.H. Contact lens sensors in ocular diagnostics. Adv. Healthc. Mater. 2015, 4, 792-810. [CrossRef]

115. Nicolson, P.C.; Vogt, J. Soft contact lens polymers: An evolution. Biomaterials 2001, 22, 3273-3283. [CrossRef]

116. Su, G.; Zhou, T.; Zhang, Y.; Liu, X.; Zhang, A. Microdynamics mechanism of D2O absorption of the poly(2-hydroxyethyl methacrylate)-based contact lens hydrogel studied by two-dimensional correlation ATR-FTIR spectroscopy. Soft Matter 2016, 12, 1145-1157. [CrossRef] [PubMed]

117. Muncan, J.; Mileusnić, I.; Rosić, J. Šakota; Vasic-Milovanovic, A.; Matija, L. Water Properties of Soft Contact Lenses: A Comparative Near-Infrared Study of Two Hydrogel Materials. Int. J. Polym. Sci. 2016, 2016, 1-8. [CrossRef]

118. Wolffsohn, J.; Mroczkowska, S.; Hunt, O.A.; Bilkhu, P.S.; Drew, T.; Sheppard, A. Crossover Evaluation of Silicone Hydrogel Daily Disposable Contact Lenses. Optom. Vis. Sci. 2015, 92, 1063-1068. [CrossRef] [PubMed]

119. Lee, C.-J.; Wu, H.; Hu, Y.; Young, M.; Wang, H.; Lynch, D.; Xu, F.; Cong, H.; Cheng, G. Ionic Conductivity of Polyelectrolyte Hydrogels. ACS Appl. Mater. Interfaces 2018, 10, 5845-5852. [CrossRef] [PubMed]

120. Dvir, T.; Timko, B.; Brigham, M.; Naik, S.R.; Karajanagi, S.S.; Levy, O.; Jin, H.; Parker, K.K.; Langer, R.; Kohane, D.S. Nanowired three-dimensional cardiac patches. Nat. Nanotechnol. 2011, 6, 720-725. [CrossRef] [PubMed]

121. Shin, S.R.; Jung, S.M.; Zalabany, M.; Kim, K.; Zorlutuna, P.; Kim, S.B.; Nikkhah, M.; Khabiry, M.; Azize, M.; Kong, J.; et al. CarbonNanotube-Embedded Hydrogel Sheets for Engineering Cardiac Constructs and Bioactuators. ACS Nano 2013, 7, 2369-2380. [CrossRef]

122. Pan, L.; Yu, G.; Zhai, D.; Lee, H.R.; Zhao, W.; Liu, N.; Wang, H.; Tee, C.K.; Shi, Y.; Cui, Y.; et al. Hierarchical nanostructured conducting polymer hydrogel with high electrochemical activity. Proc. Natl. Acad. Sci. USA 2012, 109, 9287-9292. [CrossRef]

123. Shi, Y.; Ma, C.; Peng, L.; Yu, G. Conductive "Smart" Hybrid Hydrogels with PNIPAM and Nanostructured Conductive Polymers. Adv. Funct. Mater. 2015, 25, 1219-1225. [CrossRef]

124. Know Your Dressings: Hydrogels. Available online: https://dermarite.com/know-your-dressings-hydrogels / (accessed on 12 June 2021).

125. INTRASITE $\diamond$ GEL. Available online: https://www.smith-nephew.com/key-products/advanced-wound-management/intrasitegel (accessed on 12 June 2021).

126. Hydrogel Based Product. Available online: https:/ / www.lohmann-rauscher.com/en/searchresults / ?id=2324\&L=1\&q=hydrogel+ based +product\&op= (accessed on 12 June 2021).

127. Neoheal®. Hydrogel Dressing for Wound Management. Available online: https://kikgel.com.pl/en/products/neoheal/ (accessed on 12 June 2021).

128. Woun'Dres ${ }^{\circledR C}$ Collagen Hydrogel. Available online: https:/ / www.coloplast.us/woundres-collagen-hydrogel-1-en-us.aspx (accessed on 12 June 2021).

129. Safe $n$ Simple ${ }^{\mathrm{TM}}$. Available online: www.sns-medical.com (accessed on 19 June 2021).

130. Collagen Hydrogel for Face Profi Derm Professional. Available online: https://www.cosmeticsbulgaria.com/en/product/ collagen-hydrogel-for-face-profi-derm-professional/ (accessed on 19 June 2021).

131. Advanced Génifique Light Pearl Hydrogel Melting 360 Eye Mask. Available online: https:/ /www.lancome-usa.com/skincare/ advanced-genifique-light-pearl-hydrogel-melting-360-eye-mask/LAN390.html (accessed on 19 June 2021).

132. Advanced Génifique Hydrogel Melting Sheet Mask. Available online: https://www.lancome-usa.com/skincare/advancedgenifique-hydrogel-melting-sheet-mask/LAN192.html (accessed on 19 June 2021).

133. Moira Cosmetics. Available online: https:/ / www.moirabeauty.com/search (accessed on 19 June 2021). 
134. Silicone Hydrogel Contact Lens (Daily). Available online: https:/ /www.miacare.com/weben/html/product/show.aspx?num=27 (accessed on 19 June 2021).

135. CONFiDENCE (Daily)—Black/Brown/Violet. Available online: https://www.miacare.com/weben/html/product/show.aspx? num $=29$ (accessed on 28 June 2021).

136. Charcoal Hydrogel Under Eye Masks. Available online: https://www.elfcosmetics.com/charcoal-hydrogel-under-eye-masks/50 0011.html (accessed on 28 June 2021).

137. Introducing the Breakthrough of Blue Cut Technology in Cntact Lenses. Available online: https://maxvuevision.com/v2/ (accessed on 28 June 2021).

138. Seven RX. Available online: https:/ / markennovy.com/our_products/seven-rx/ (accessed on 28 June 2021).

139. CLINICAL RESOURCE: A Case Study Using ActivHeal®Hydrogel and ActivHeal®Hydrocolloid to Promote Autolytic Debridement of an Acute Wound - Hydrocolloid. Available online: http:/ / www.activheal.com/?s=hydrogel (accessed on 28 June 2021).

140. NU-GEL ${ }^{\mathrm{TM}}$ Hydrogel with Alginate. Available online: https://www.kciuk.co.uk/healthcare-professionals/uk-product-catalog/ catalog/nu-gel-hydrogel-with-alginate (accessed on 28 June 2021).

141. The only FDA-Approved, Once-Yearly CPP Treatment. Available online: https://www.supprelinla.com/patients/what-issupprelin-la/ (accessed on 28 June 2021).

142. Cervidil. Available online: https:/ / www.rxlist.com/cervidil-drug.htm (accessed on 28 June 2021).

143. SQZgel ${ }^{\mathrm{TM}}$. Available online: https:/ / www.researchgate.net/publication/329529474_SQZgel (accessed on 28 June 2021).

144. Mebiol $® G e l$. Available online: https://www.cosmobiousa.com/products/mebiol-gel (accessed on 28 June 2021).

145. GelrinC Overview. Available online: http://www.regentis.co.il/products.asp (accessed on 28 June 2021).

146. Mebiol Gel®. Available online: https://search.cosmobio.co.jp/cosmo_search_p/search_gate2/docs/MBG_/PMW205001COS.20 180608.pdf (accessed on 28 June 2021).

147. HyStem ${ }^{\mathrm{TM}}$ Hyaluronic Acid Based Hydrogels for 3D Cell Culture Applications. Available online: https://www.sigmaaldrich. com/technical-documents/articles/biology/hystem-3d-hydrogels.html (accessed on 5 July 2021).

148. Corning ${ }^{\circledR P u r a M a t r i x}{ }^{\mathrm{TM}}$ Peptide Hydrogel. Available online: https://www.corning.com/media/worldwide/global/documents/ faq_DL_028_Corning_PuraMatrix_Peptide_Hydrogel.pdf (accessed on 5 July 2021).

149. Synthetic Peptide Hydrogel. Available online: https://www.biogelx.com/technology-synthetic-peptide-hydrogel-2/ (accessed on 5 July 2021).

150. SpaceOAR ${ }^{\mathrm{TM}}$ Hydrogel. Available online: https://www.bostonscientific.com/en-US/products/hydrogel-spacers/spaceoarhydrogel.html (accessed on 5 July 2021).

151. Bulkamid: For the Treatment of Stress Urinary Incontinence. Available online: https:/ / bulkamid.com/\# (accessed on 5 July 2021).

152. VersaGel®/Symphony ${ }^{\circledR 3 D}$ Cell Culture Platform by Cypre Inc. Available online: https://www.selectscience.net/products / versagel----symphony---3d-cell-culture-platform/?prodID=210830 (accessed on 5 July 2021).

153. Hydrogel Cathetor. Available online: https://www.medtronic.com/covidien/en-us/search.html\#q=hydrogel\%20cathetor (accessed on 5 July 2021).

154. Bolt ${ }^{\mathrm{TM}} 12 \%$, Bis-Tris, $1.0 \mathrm{~mm}$, Mini Protein Gel, 12-well. Available online: https://www.thermofisher.com/order/catalog/ product/NW00122BOX?SID=srch-srp-NW00122BOX\#/NW00122BOX?SID=srch-srp-NW00122BOX (accessed on 5 July 2021).

155. Catoira, M.C.; González-Payo, J.; Fusaro, L.; Ramella, M.; Boccafoschi, F. Natural hydrogels R\&D process: Technical and regulatory aspects for industrial implementation. J. Mater. Sci. Mater. Med. 2020, 31. [CrossRef]

156. Donawa, M.E. Regulation of novel biomedical hydrogel products. In Biomedical Hydrogels; Springer: Berlin/Heidelberg, Germany, 2011.

157. RULES OF PROCEDURE. Available online: https://ec.europa.eu/health/sites/default/files/scientific_committees/docs/rules_ procedure_2016_en.pdf. (accessed on 20 August 2021).

158. Inactive Ingredient Search for Approved Drug Products. Available online: https://www.accessdata.fda.gov/scripts/cder/iig/ index.cfm (accessed on 20 August 2021). 